\title{
The poverty-reducing effect of Medicaid
}

\section{Citation}

Sommers, Benjamin D., and Donald Oellerich. 2013. "The Poverty-Reducing Effect of Medicaid." Journal of Health Economics 32 (5) (September): 816-832. doi:10.1016/j.jhealeco.2013.06.005.

\section{Published Version}

doi:10.1016/j.jhealeco.2013.06.005

\section{Permanent link}

http://nrs.harvard.edu/urn-3:HUL.InstRepos:14008375

\section{Terms of Use}

This article was downloaded from Harvard University's DASH repository, and is made available under the terms and conditions applicable to Other Posted Material, as set forth at http:// nrs.harvard.edu/urn-3:HUL.InstRepos:dash.current.terms-of-use\#LAA

\section{Share Your Story}

The Harvard community has made this article openly available.

Please share how this access benefits you. Submit a story.

Accessibility 


\title{
THE POVERTY-REDUCING EFFECT OF MEDICAID*
}

\author{
Benjamin D. Sommers $^{\mathrm{a}} \quad$ Donald Oellerich $^{\mathrm{b}}$
}

\begin{abstract}
:
Medicaid provides health insurance for 54 million Americans. Using the Census Bureau's supplemental poverty measure (which subtracts out-of-pocket medical expenses from family resources), we estimated the impact of eliminating Medicaid. In our counterfactual, Medicaid beneficiaries would become uninsured or gain other insurance. Counterfactual medical expenditures were drawn stochastically from propensity-score-matched individuals without Medicaid. While this method captures the importance of risk protection, it likely underestimates Medicaid's impact due to unobserved differences between Medicaid and non-Medicaid individuals. Nonetheless, we find that Medicaid reduces out-of-pocket medical spending from $\$ 871$ to $\$ 376$ per beneficiary, and decreases poverty rates by $1.0 \%$ among children, $2.2 \%$ among disabled adults, and $0.7 \%$ among elderly individuals. When factoring in institutionalized populations, an additional 500,000 people were kept out of poverty. Overall, Medicaid kept at least 2.6 million - and as many as 3.4 million - out of poverty in 2010, making it the U.S.'s third largest anti-poverty program.
\end{abstract}

Keywords: Medicaid, health insurance, poverty, medical costs

\section{JEL Codes: I13, I32, I38, D31 Word Count: 7737}

\author{
Contact information: \\ a - Benjamin D. Sommers \\ (corresponding author) \\ Harvard School of Public Health \\ AND \\ U.S. Department of Health and Human Services \\ 677 Huntington Avenue, Room 406 \\ Boston, MA 02115 \\ Phone: 617-432-3271 \\ Fax: 617-432-4494 \\ Email: bsommers@hsph.harvard.edu \\ b - Donald Oellerich \\ Office of the Assistant Secretary for \\ Planning and Evaluation \\ U.S. Department of Health and Human Services \\ 200 Independence Ave SW \\ Washington, DC 20201 \\ Phone: 202-690-8410 \\ Fax: 202-690-6562 \\ Email: don.oellerich@hhs.gov

\footnotetext{
* We are grateful to Sherry Glied, Richard Kronick, Nancy De Lew, Robert Moffit, and two anonymous reviewers for helpful comments and advice. We also appreciate the research assistance of John Boney. Any remaining errors are solely the authors' responsibility. This research was supported through the authors' employment at the U.S. Department of Health and Human Services. No additional funding was provided. This work represents the opinions of the authors and in no way represents the Department of Health and Human Services or any other government agency.
} 


\section{THE POVERTY-REDUCING EFFECT OF MEDICAID}

\section{Highlights}

- We model the impact of Medicaid on out-of-pocket spending.

- We then calculated Medicaid's poverty-reducing impact using the Census Bureau's supplemental poverty measure.

- Medicaid reduced out-of-pocket medical spending per enrollee from \$871 to \$376 per year.

- Medicaid kept 2.6 million Americans out of poverty in 2010, making it the third-largest anti-poverty program in the U.S.

- Poverty-reducing effects of Medicaid were greatest for disabled adults, the elderly, children, and racial/ethnic minorities. 


\section{INTRODUCTION}

Medicaid is the single largest source of health coverage in the United States, covering nearly one in every five Americans - 54 million as of the most recent government data (Truffer, Klemm et al. 2012). Medicaid provides health insurance to low-income children, parents of dependent children, people with disabilities, and the elderly. Thus, it represents one of the largest means-tested programs in the United States. Yet, its purpose has been primarily framed as one designed to improve access to health care and potentially even improve health (Currie and Gruber 1996; Currie and Gruber 1996; Long, Coughlin et al. 2005; Finkelstein, Taubman et al. 2011; Sommers, Baicker et al. 2012), while its potential poverty-reducing effects have not been as well characterized.

The importance of Medicaid's role in reducing poverty has presumably grown during the recent recession, with the program's enrollment increasing by more than $25 \%$ from 2007 to 2010 (DeNavas-Walt, Proctor et al. 2011). Its poverty-reducing role is likely to become even more prominent with a large expansion of Medicaid eligibility slated for 2014 under the Affordable Care Act.

In this paper, we use a novel measure - the Supplemental Poverty Measure (SPM) - and new variables in the 2011 Current Population Survey, including medical out-of-pocket (MOOP) spending, to estimate the poverty-reducing effects of the Medicaid program. The Census Bureau's SPM subtracts out-of-pocket medical expenses (including premiums) in its calculation of family resources, while adding in the value of tax and in-kind transfer programs (not including Medicaid). We used this new measure to assess the impact of Medicaid on poverty. Our objective was to estimate the number of additional Americans who would be defined as poor 
$(<100 \%$ of the federal poverty level, FPL) or extremely poor $(<50 \%$ of FPL $)$, in the absence of the Medicaid program.

Medicaid's poverty-reducing effects take two forms - one is the reduction in expected or mean medical out-of-pocket spending (essentially, an in-kind transfer analogous to the Earned Income Tax Credit); the second is traditional insurance, protecting individuals against the relatively unlikely event of high out-of-pocket medical spending associated with serious illness. Prior research has focused primarily on the former (Burtless and Siegel 2001; Ziliak 2011). For instance, from 1979 until 2003, the Census Bureau published alternative poverty measures that added to a family's resources either the "fungible value" or market value of Medicaid. "Fungible value" equates the value of coverage to a market-rate premium for Medicaid, but only for households with incomes above a threshold level of "basic food and housing requirements." Another approach uses a market-based value of insurance for everyone with Medicaid, regardless of income. A final alternative, which has been used to study the impact of Medicare coverage, uses a utility-based value of insurance based on expected spending and risk aversion (McClellan and Skinner 2006; Finkelstein and McKnight 2008).

All approaches have significant limitations, particularly for the low-income population in Medicaid. Fungible value underestimates the value of coverage to extremely low-income households - for whom it may even be $\$ 0$ (Weicher 1999) - while market value conflates premiums with overall out-of-pocket medical spending, which may be higher or lower than

\footnotetext{
1 The fungible approach for valuing medical coverage assigns income to the extent that having the insurance would free up resources that would have been spent on medical care. The estimated fungible value depends on family income, the cost of food and housing needs, and the market value of the medical benefits. If family income is not sufficient to cover the family's basic food and housing requirements, the fungible value methodology treats Medicare and Medicaid as having no income value. If family income exceeds the cost of food and housing requirements, the fungible value of Medicare and Medicaid is equal to the amount which exceeds the value assigned for food and housing requirements (up to the amount of the market value of an equivalent insurance policy; i.e., total cost divided by the number of participants in each risk class). http://www.census.gov/hhes/www/income/data/historical/measures/redefs.html
} 
comparable private market premiums. ${ }^{2}$ Thus, by definition, the fungible value of Medicaid has little impact on poverty, while the market value approach substantially reduces poverty even for those with very little cash income or health care utilization. Furthermore, while market value may be a reasonable proxy for the value of coverage for individuals who would otherwise purchase their own insurance at market rates, it is an inappropriate measure (and likely a marked overestimate) for Medicaid enrollees who would otherwise be uninsured. In the latter group, utilization will decline with the loss of coverage due to both a wealth effect and price effect (as the effective coinsurance rate rises to $100 \%$ ). Lastly, the utility-based approach to valuing insurance is highly sensitive to parametric assumptions about risk aversion about which there is no consensus value in the literature (Finkelstein and McKnight 2008), and likely underestimates the value of coverage for individuals with incomes near zero, as is the case for many in Medicaid.

Medicaid reduces out-of-pocket spending, compared to private insurance and being uninsured, through several mechanisms. First, compared to private coverage, Medicaid generally requires no premiums. Second, Medicaid typically features generous benefit plans, which often pay for services that are not well-covered (if at all) by private insurance, such as home health, mental health services, and long-term care (O'Brien 2005). Third, Medicaid's costsharing requirements are far lower than most private insurance plans (Heberlein, Brooks et al. 2011), and generally impose much less financial burden compared to what most uninsured individuals must pay when obtaining care (Weissman, Stern et al. 1991). Taken together, the potential impact on low-income individuals is significant; we seek here to quantify this benefit,

\footnotetext{
${ }^{2}$ Out-of-pocket medical spending includes both household payment towards premiums and cost-sharing requirements, such as co-pays, deductibles, and coinsurance. For a person paying for his full premium, out-ofpocket spending will by definition be at least as large as premium payments. But for an individual who would otherwise choose to be uninsured, valuing Medicaid as the price of a comparable insurance premium overstates that value of that coverage.
} 
which is distinct from whatever gains in heath care access or health status that the program confers.

In this paper, we estimate the impact of Medicaid coverage on household finances by modeling overall out-of-pocket medical spending. To do so, we compare two alternative scenarios. The first is the status quo. The second is the counterfactual in which Medicaid no longer exists, and individuals currently enrolled in Medicaid are either uninsured or enrolled in other insurance such as private coverage or Medicare. In this latter scenario, the main empirical challenge is estimating what the out-of-pocket spending would be for current Medicaid beneficiaries if they were no longer in Medicaid. We present two analytical approaches, as well as numerous sensitivity analyses. One approach is a non-stochastic model, which captures only the "in-kind transfer" effect of Medicaid based on the mean expected change in out-of-pocket spending. In contrast, our preferred approach presents a stochastic model of medical spending, which captures both the in-kind transfer and risk-protection effects of Medicaid.

1) Stochastic Model Using Propensity-Score Matching: In our preferred approach, we matched individuals with Medicaid coverage to those without Medicaid coverage (primarily a combination of those with private coverage and uninsured individuals), using a propensity-score method. Within each propensity score decile (stratified by age and disability status), stochastic values of out-of-pocket medical spending were drawn for each individual with Medicaid based on the observed distribution of spending among the matched controls. This method assigns each person in Medicaid a random level of spending from a distribution of similar individuals who did not have Medicaid coverage.

2) Non-Stochastic Model Using Fixed Ratios and Propensity-Score Matching: In this approach, we again match individuals with Medicaid to those without Medicaid using 
propensity scores. Then we inflate the observed out-of-pocket spending for each Medicaid enrollee using the mean ratio of non-Medicaid-to-Medicaid out-of-pocket spending within each propensity-score decile.

For both approaches, we calculated the net change in percentage and number of Americans living in poverty and extreme poverty in the absence of the Medicaid program, as well as the mean change in out-of-pocket medical spending and family income for individuals currently enrolled in Medicaid.

Using our preferred stochastic model, we estimate that in 2010, Medicaid kept 2.1 million Americans out of poverty and 1.4 million out of extreme poverty. In the absence of Medicaid coverage, total out-of-pocket medical spending would have increased from $\$ 376$ to $\$ 871$ per Medicaid enrollee, with family income dropping from $149 \%$ to $143 \%$ of FPL. Subgroup analyses indicated that the greatest poverty-reducing effects were concentrated among disabled adults, children, the elderly, and racial/ethnic minorities. The potential for unobserved differences between Medicaid individuals and the propensity-matched non-Medicaid controls (who may be healthier and have greater availability of alternative insurance options not fully captured by observed variables) suggests that these numbers likely underestimate Medicaid's impact. A Heckman selection model that attempts to account for this bias produced a somewhat higher estimate, with 2.6 million Americans kept out of poverty.

The non-stochastic approach yielded similar average income effects as our preferred model, but with lower estimates of poverty reduction. In the absence of Medicaid coverage, total out-of-pocket medical spending would have increased from $\$ 376$ to $\$ 819$ per Medicaid enrollee, with family income dropping from $149 \%$ to $144 \%$ of FPL. But the overall poverty reduction was 
much smaller when we ignored the risk protection inherent in Medicaid coverage: this nonstochastic approach produces an estimate that Medicaid kept 1.5 million Americans out of poverty and 1.0 million out of extreme poverty.

In terms of alternative insurance coverage, our preferred model indicates that in the absence of Medicaid, among individuals currently in the program $42 \%$ would have private insurance through an employer, $5 \%$ would have non-group private coverage, $12 \%$ would have Medicare, and 40\% would be uninsured. ${ }^{3}$ While these results fall within the range of estimates of private insurance crowd-out by Medicaid - which are as high as $60 \%$ in one study (Gruber and Simon 2008) - given significant differences in study sample and methods, we caution that our findings are not directly comparable to those in the crowd-out literature.

In an analysis of institutionalized populations, we offer an estimate from the American Community Survey than in the absence of Medicaid's coverage for long-term costs, an additional 500,000 institutionalized Americans (mostly elderly and disabled individuals) would have lived under the poverty level, and 850,000 more would have lived in extreme poverty.

Our results build on prior research in several strands of public and health economics. First, our work presents a national, population-based estimate of the impact of Medicaid on household finances, adding additional evidence similar to a recent analysis of Oregon's Medicaid program (Finkelstein, Taubman et al. 2011). In that study, a lottery was used to identify the effects of Medicaid coverage, which was shown to significantly reduce both out-of-pocket medical expenditures (by approximately $\$ 800$ per adult per year, compared to our estimate of

\footnotetext{
${ }^{3}$ Note that some individuals in our sample report multiple types of coverage. Some had private insurance (17.6\%) or Medicare (13.2\%) in addition to Medicaid at baseline. This includes elderly individuals, who are essentially all $(98.0 \%)$ covered by Medicare as well. For our estimates of alternative coverage, we exclude those reporting both Medicaid and private insurance at baseline. We also use a health insurance hierarchy as follows, in which we report coverage based on the following priority list: Medicare, employer-sponsored insurance (ESI), non-group private insurance, and then uninsured. For all other analyses in our paper, including estimates of overall poverty reduction, all individuals are included in the sample, including those with multiple types of coverage.
} 
roughly $\$ 500$ per person) and the risk of having medical debts sent to a collection agency. Our work also builds on prior analysis of the impact of the creation of Medicare in 1965 on out-ofpocket spending, which led to an estimated $40 \%$ reduction in out-of-pocket spending for those in the top quartile of spending (Finkelstein and McKnight 2008); the relative reduction we find for Medicaid is significantly larger (roughly $60 \%$ on average), which is consistent with the minimal cost-sharing requirements in Medicaid compared to Medicare.

Second, our results allow us to place the poverty-reducing effects of Medicaid in the context of other public programs. We find that Medicaid's impact places it as the third most successful anti-poverty program in the U.S. (Ziliak 2011), behind the Earned Income Tax Credit (EITC) and the Supplemental Nutritional Assistance Program (SNAP, known as food stamps).

The rest of this paper is structured as follows. Section II presents background on the Medicaid program and a simple model of health insurance choice and medical care expenditures. Section III presents our data sources and analytic approach. Section IV presents our main results. Section V discusses our findings, presents comparisons to other poverty reducing programs, and concludes.

\section{OVERVIEW OF MEDICAID AND A MODEL OF HEALTH INSURANCE CHOICE}

\section{II.A Medicaid}

Medicaid is a joint state-federal program that provides health insurance to low-income individuals in certain categories of eligibility: persons with disabilities, pregnant women, parents and caretakers with dependent children in the home, and children 18 or younger. In a handful of states, adults without disabilities or dependent children are eligible for Medicaid under special Section 1115 waivers obtained from the Centers for Medicare and Medicaid Services (CMS) 
(Kaiser 2009). As of 2010, Medicaid provided coverage to approximately 54 million individuals, $9 \%$ of whom are elderly, $18 \%$ disabled, $23 \%$ other adults, and $50 \%$ children (Truffer, Klemm et al. 2012). Within each of these eligibility categories, eligibility criteria are set by states, subject to specific federal minimum guidelines. Mandatory guidelines currently cover children under age 6 and pregnant women with family incomes at or below $133 \%$ of the Federal Poverty Level (FPL), children 6 to 18 up to 100\% FPL, families with children who meet their state's old requirements for Aid to Families with Dependent Children (AFDC) as of July 1996, and most disabled individuals receiving Supplemental Security Income.

Benefits in Medicaid are typically quite generous, covering inpatient, outpatient, diagnostic services, and prescription drugs. Medicaid is also the single largest payer for longterm care in the U.S. Cost-sharing requirements are generally smaller than in other insurance types, though some states charge enrollees as much as $\$ 3$ for certain prescriptions and $\$ 100$ or \$200 for inpatient admissions (Ross, Jarlenski et al. 2009).

One key consideration for assessing the poverty-reducing impact of Medicaid is assessing what the likely insurance coverage would be for individuals if they were not in Medicaid. Approximately 8 million individuals - low-income elderly and disabled persons - are dually enrolled in Medicaid and Medicare, and presumably would remain in Medicare in the absence of Medicaid, though they would face significantly greater out-of-pocket expenses due to Medicare's Part B and D premiums, a coinsurance rate of $20 \%$ on outpatient services, and a Part A deductible of nearly $\$ 1200$ for hospitalizations. ${ }^{4}$ Among the remaining individuals, a portion would likely acquire private insurance, either though employers or the nongroup market, while others would be unable to afford or unwilling to purchase private coverage. Numerous studies

\footnotetext{
${ }^{4}$ See "Medicare premiums and coinsurance rates for 2012," Centers for Medicare and Medicaid Services. http://questions.medicare.gov/app/answers/detail/a_id/2309.
} 
have assessed this question in reverse, that is to say, what proportion of individuals who enroll in Medicaid when eligibility is expanded were previously uninsured versus privately insured. Estimates of "crowd-out" of private coverage by Medicaid range from a maximum of $60 \%$ to nearly negligible crowd-out, depending on the data source and definition used (Cutler and Gruber 1996; Thorpe and Florence 1998; Blumberg, Dubay et al. 2000; Gruber and Simon 2008; Hamersma and Kim 2013). Our baseline analysis allows for significant private insurance crowdout, but we also explicitly model a scenario with no private insurance crowd-out as a sensitivity analysis.

\section{II.B Consumer Model of Insurance Choice and Health Care Utilization}

We present a simple model for the choice of insurance type among individuals eligible for Medicaid based on the distribution of possible out-of-pocket expenditures, adapted from an similar exploration of the impact of Medicare's creation on out-of-pocket spending (Finkelstein and McKnight 2008).

The model uses the expected utility framework and contains three distinct insurance states: Medicaid coverage, private health insurance, and being uninsured. Medicare coverage is taken as exogenous, since enrollment is automatic for those qualifying for Social Security old age survivor and disability income (OASDI). ${ }^{5}$ We treat the individual's utility $u(c, \pi)$ as a function of non-health consumption $c$ and an effective premium $\pi$, which consists both of direct financial costs of coverage as well as non-financial costs, which in the case of obtaining Medicaid coverage may be substantial - such as the opportunity cost of completing the Medicaid application process and potential stigma of obtaining means-tested insurance (Remler and Glied

\footnotetext{
${ }^{5}$ Of course, whether or not a person under age 65 applies for OASDI is itself a consumer decision, but we treat that here as a decision that choice that has been made independent of the availability of Medicaid and precedes Medicaid enrollment for the purposes of our counterfactual.
} 
2003). $Y$ represents income, before premiums and any out-of-pocket medical spending. $M$ represents medical out-of-pocket spending, a non-negative random variable with probability density function $f(M)$. The function $f(-)$ depends on the type of health insurance, $H$ : Medicaid, or, and private coverage. $u(-)$ is concave, corresponding to a risk-averse consumer. The individual maximizes expected utility by choosing insurance type $\mathrm{H}$, given the equation:

$$
\underset{h}{\operatorname{Max}} \int u\left(Y-M-\pi_{H}\right) f_{H}(M) d M
$$

Our reduced-form empirical analysis focuses on those individual-level variables that have been shown in previous research to impact the parameters $\pi_{H}$ and the distribution $f_{H}(-)$. The next section describes the empirical approach, and we return briefly to this model in Section IV.E, when we estimate the potential economic gains through decreased risk exposure in Medicaid.

\section{DATA AND METHODS}

\section{III.A Data}

\section{III.A.1 Overview of the Current Population Survey}

Our data come from the 2011 Current Population Survey's Annual and Social Economic Supplement (CPS), conducted by the U.S. Census Bureau. The survey contains a nationallyrepresentative sample of all civilian non-institutionalized individuals, and features detailed information on sources and amounts of income for each household member; program participation; health insurance; and basic demographics. In all of our analyses, we used the full sample $(n=204,983)$ and Census survey weights to produce population-wide estimates.

The CPS is the most widely used data source on insurance coverage in the U.S., and has been used for numerous analyses of Medicaid coverage (Cutler and Gruber 1996; Kronebusch and Elbel 2004; Busch and Duchovny 2005). For the purposes of our analysis, we treat Medicaid 
and the Children's Health Insurance Program (CHIP) as a single entity, since the programs are closely related and the CPS data do not reliably distinguish the two. Of note, in 2010, the CPS added questions about medical out-of-pocket spending (MOOP), including insurance premiums and cost-sharing requirements. Previous research demonstrates that these items have produced high-quality estimates of spending comparable to other data sources (Caswell and O'Hara 2010).

However, the CPS does have several notable limitations. First, the survey doesn't include institutionalized population (e.g. long-term care), for which Medicaid is the single largest payer in the U.S. This means that our primary analysis measures the poverty reducing effects of Medicaid coverage for acute care, outpatient, and home-based services, but necessarily excludes residential long-term care. We use an alternative Census data source, the American Communities Survey, to explore the role of Medicaid for institutionalized individuals, discussed further in Section III.C.

Second, the structure of the CPS health insurance questions creates ambiguity about precisely what individuals are reporting. Ostensibly, the survey asks about each person's insurance coverage throughout the prior calendar year, and allows for multiple forms of coverage. Thus, an individual who reports "Medicaid" may have had Medicaid for 1 month 12 months, or anywhere in between, with or without alternative coverage during that time. This is relevant because previous research shows that Medicaid coverage - particularly for adults - is often unstable, with frequent gaps even among those who are eligible, due to burdensome renewal requirements for ongoing coverage (Sommers 2009). Despite the technical wording of the question (about the prior calendar year), some argue that CPS estimates are closer in fact to “point-in-time” results regarding insurance coverage (Swartz 1986; Orszag 2007). We follow this latter approach in our interpretation of the CPS data, though this is primarily an issue of 
framing the magnitude of our results (i.e., that our findings apply to the poverty effects of all those with Medicaid a given point in time, as opposed to anyone with Medicaid during the course of the year). But this assumption does not significantly affect our analytical framework using these data.

Finally, comparisons of the CPS to administrative data reveal a lower number of people reporting Medicaid coverage than do the state Medicaid enrollment files (approximately 49 million versus 54 million using 2011 data) (DeNavas-Walt, Proctor et al. 2011; Truffer, Klemm et al. 2012). The majority of enrollees who do not report Medicaid appear to mistakenly report private insurance (Call, Davidson et al. 2008), perhaps confusing Medicaid managed care for private coverage. However, others have speculated that administrative files may contain people who are unaware they are still enrolled in Medicaid, and may in fact double count individuals (Dubay, Holahan et al. 2007). For our purposes, we take the coverage reported in the CPS at face value without any additional imputation of Medicaid/CHIP coverage - which may result in an underestimate of the poverty-reducing impact of the Medicaid program.

\section{III.A.2 The Supplemental Poverty Measure}

It has long been recognized that the current official definition of poverty does not adequately represent the needs of families or the resources available to them (Citro and Michael 1995; Ruggles 1995). The official poverty measure was developed in 1963, and counts only cash income as "family resources." Not only have the consumption patterns of Americans changed significantly in the last 40 years, but there have also been dramatic changes in the nation's safety net. For example, in 2010 , social safety net spending included over $\$ 65$ billion in SNAP and $\$ 58$ billion from EITC, but these are not accounted for in the official poverty measure. Public health 
insurance (including Medicare, Medicaid and CHIP), non-existent in the 1950's, now accounts for over $\$ 900$ billion in federal and state spending. In light of these and other demographic and economic changes, the Census Bureau recently published the Supplemental Poverty Measure (SPM), based primarily on the recommendations of the National Academy Panel on poverty measurement (Citro and Michael 1995) and a federal interagency working group. ${ }^{6}$

The SPM has several key distinctions from the official poverty measure (Short 2011). First, the SPM uses revised family units, which include unmarried partners in the same unit. Then, to each family's total pre-tax income, the SPM adds in the Census-measured cash-value of transfers such as SNAP, Women, Infants, and Children (WIC) nutritional assistance, and EITC, among others (but not public health insurance). Thus, the SPM refers technically to "family resources," rather than "family income." Then the SPM subtracts from family resources taxes, work expenses, and child support paid. Notably, the SPM also subtracts from resources each family's out-of-pocket medical spending, which includes premiums, cost-sharing, and spending on non-covered services. This yields a total estimate of net available resources for each family. Next, the SPM requires the use of a different poverty threshold for each family, based on family size and composition, as well as home ownership and geographic cost-of-living (Renwick 2009; Short 2011). The final step is expressing each family's resources as a percentage of the SPM poverty threshold.

\section{III.B Data Analysis}

\section{III.B.1 Empirical Framework}

\footnotetext{
${ }^{6}$ See the Observations from the Interagency Technical Working Group on Developing a Supplemental Poverty Measure 2010 http://www.census.gov/hhes/www/poverty/SPM TWGObservations.pdf
} 
Our empirical approach requires three major components. First, we adopted the family unit structure and measures of family resources and poverty threshold used in the Census Bureau's 2011 Supplemental Poverty Measure (SPM) dataset, downloaded directly from the Census Bureau. Then, we modeled two different scenarios: the status quo, in which approximately 50 million individuals in the CPS reported having Medicaid coverage; and the counterfactual scenario, a hypothetical absence of the Medicaid program in which individuals currently in the program are instead uninsured or enrolled in Medicare or private insurance. Lastly, we compared outcomes in the status quo versus the counterfactual, using several outcomes designed to measure the poverty-reducing impact of the Medicaid program: net change in percentage and number of people living in poverty $(\leq 100 \% \mathrm{FPL})$ and extreme poverty $(\leq 50 \%$ FPL) by age and disability status; net change in household resources as a percentage of the FPL; and net change in out-of-pocket medical spending per person previously enrolled in Medicaid. We also compared these outcomes by race/ethnicity, gender, and Census region. In a sensitivity analysis, we compared our results using a version of the official poverty measure in lieu of the SPM.

\section{III.B.2 Predicting Out-of-Pocket Expenditures for Medicaid Enrollees}

As outlined in Section I, we present two distinct approaches for modeling the counterfactual of what MOOP would have been for individuals currently covered by Medicaid: a stochastic method using propensity score matching and random draws from the matched distribution of out-of-pocket spending (our preferred approach), and a non-stochastic method - a propensity score model using fixed ratios of Medicaid-to-non-Medicaid spending. 
In both methods, we use propensity scores to address the selection bias in which types of people are enrolled in Medicaid. The propensity score method enables a comparison of individuals to appropriate controls across a multi-dimensional set of variables that may affect both out-of-pocket spending and the likelihood of Medicaid coverage (Dehejia and Wahba 2002). An additional key advantage is that the use of propensity score deciles enables us to generate a distribution for stochastic draws for out-of-pocket spending, avoiding the pitfall of non-stochastic regression models that focus only on explaining the mean rather than the full distribution of values (Gilleskie and Mroz 2004).

The assumption underlying our use of the propensity score method is that the differences between Medicaid and non-Medicaid individuals related to their out-of-pocket health care costs are fully captured in our list of observable variables. In the language of the model presented in Section II.B, we are assuming that $f(M)$, the underlying probability density function for out-ofpocket medical spending, is identical for individuals within a given propensity score decile. While we used a comprehensive list of individual-level and policy-level variables in our propensity score, including demographics, income, self-reported health status, disability status, state of residence, and Medicaid eligibility rules, it is likely that some unmeasured differences remain. Propensity scores do not rectify the bias created by unmeasured variables. While regression-based selection models with fitted values might be better in some ways at addressing selection bias, a major disadvantage is that such an approach would not allow us to factor in the stochastic element of out-of-pocket spending. Fitted values, by construction, yield values closer to the mean. Given the skewed nature of medical spending, this means that regression-fitted cost estimates may be too high for the majority of the sample (biased upwards by outliers), while the tail end of the distribution may be too close to the mean (Gilleskie and Mroz 2004), creating an 
uncertain impact on overall estimates in our analysis. For instance, in all age and eligibility groups in our sample, out-of-pocket spending for individuals not in Medicaid demonstrated marked dispersion and positive skewness. The $10^{\text {th }}$ and $90^{\text {th }}$ percentiles, respectively, were $\$ 0$ and $\$ 880$ for children (median $\$ 110$ ), $\$ 0$ and $\$ 5050$ for non-disabled adults under 65 (median \$550), \$0 and \$6253 (median \$900) for disabled adults, and \$35 and \$5528 (median \$1440) for elderly adults.

Thus, our approach prioritizes measuring the stochastic nature of medical spending, at the potential expense of less comprehensively addressing selection bias. To the extent that our propensity score method does not fully eliminate this selection bias, we expect that our approach would underestimate the total impact of Medicaid, because unobservable features of Medicaid enrollees likely make them even sicker and more costly than non-Medicaid individuals. To test the possible extent of this effect, we also present a non-stochastic method using a Heckman sample selection model, described in Section III.B.5, which provides an estimate of the upper bound of Medicaid's effect related to omitted variable bias.

We also conduct several sensitivity analyses with variable approaches to factoring selfreported health into the propensity score, as a method for estimating how much bias the lack of other more comprehensive health measures may have on our analysis. At one extreme, we stratify our propensity matching explicitly based on self-reported health status, and at the other extreme, we exclude health status from the matching process entirely.

We also present an alternative propensity score matching analysis in which the controls are limited to those individuals without private coverage, since individuals who are uninsured or have Medicare coverage (among the elderly and disabled) may more closely resemble Medicaid beneficiaries on relevant unobservable dimensions than do those with private health insurance. 
III.B.3 Stochastic Model: Propensity Score Matching with Random Draws from the Observed Spending Distribution

In this approach, we began by matching individuals with Medicaid to those without Medicaid using propensity scores. We then used stochastic draws to model spending in the counterfactual scenario, following previous research in settings ranging from the use of stochastic wages to model the impact of Social Security (van der Klaauw and Wolpin 2008) to using stochastic medical spending to model the impact of expanding government-provided health insurance (Gilleskie 1998). Within each propensity score decile, stochastic values were randomly drawn for each individual with Medicaid from the observed distribution of MOOP among non-Medicaid individuals from the same decile.

Propensity scores were modeled using the following linear probability model:

$$
\text { Mcaid }_{i j}=\beta_{0}+\beta_{1} X_{i}+\beta_{2} \text { Income }_{f}+\beta_{3} \text { ImputedEligible }_{i j j} * \text { State }_{j}+\varepsilon_{i f j}
$$

where $i$ indexes individuals, $f$ the family unit, and $j$ the state. The dependent variable Mcaid $_{i f j}$ is a dummy variable for the presence of Medicaid coverage. $X_{i}$ is a vector of individual-level variables that related to the probability of being eligible for Medicaid and/or the probability of enrollment conditional on eligibility. Previous research demonstrates that Medicaid take-up is highly variable by eligibility group, with high participation rates among eligible disabled adults (76\%) and children (85\%), with much lower rates among parents (57\%) and childless adults (38\%) (Kenney, Lynch et al. 2011; Sommers, Tomasi et al. 2012). Variation across states is equally pronounced, with state-specific take-up rates among adults ranging from $44 \%$ to $88 \%$ (Sommers, Tomasi et al. 2012). To model these issues, our propensity scores are stratified by eligibility pathway, and then include the following covariates: age, self-reported health (on a five 
point scale), educational attainment, citizenship, employment status, student status, race, ethnicity, gender, marital status, imputed pregnancy status, ${ }^{7}$ and the additional income and eligibility measures listed below.

Income $_{f}$ is a vector describing family income, which includes a set of dummy variables for specific ranges of low income defined by the Census Bureau $(<100 \%, 100-124 \%, 125-149 \%$, and $>150 \% \mathrm{FPL}$ ), as well as a linear family income variable expressed as a percentage of FPL. This approach allows for maximum flexibility in accounting for the previously-documented nonlinearities in the relationship between income and Medicaid participation (Hamersma and Kim 2013), as well as linear effects within each income band.

ImputedEligible is a dummy variable for whether an individual meets state-specific criteria for Medicaid eligibility (Kaiser 2009; Kaiser 2010; Heberlein, Brooks et al. 2011). State ${ }_{j}$ is a vector of state fixed effects (plus the District of Columbia, which has its own Medicaid program). Our models include these somewhat overlapping categories of imputed eligibility, income, and state of residence for two reasons. Imputed eligibility in survey data is only an approximation and by construction imperfect, which means that these variables may have independent predictive power even beyond a strict application of the state eligibility rules. Second, prior research demonstrates that among eligible individuals take-up of Medicaid varies widely based on demographic factors and state of residence (Sommers, Tomasi et al. 2012), which is best modeled using the flexibility of interaction terms between state of residence and imputed eligibility.

We used five distinct categories for modeling Medicaid enrollment, based on the predominant eligibility pathways in the program: 1) children (defined as 0-18 for Medicaid

\footnotetext{
${ }^{7}$ CPS does not directly ask about pregnancy. Since the CPS covers the full prior year of data, we impute pregnancy status to any mother of a child under 1 year old. Age was coded in the following categories: $0-1,2-5,6-12,13-18$, 19-24, 25-30, 31-40, 41-50, 51-64, 65 and older.
} 
eligibility purposes); 2) adults with disabilities (19-64); ${ }^{8} 3$ ) non-disabled parents (19-64); 4) childless adults (19-64); and 6) elderly adults (65 and older). Each propensity score model was fitted separately for these groups, since the relationship between each covariate and the likelihood of Medicaid may differ across groups. For each model, we then used predicted values of the dependent variable to generate propensity scores for the likelihood of Medicaid coverage. We divided the sample into propensity score deciles, to match individuals in Medicaid to individuals not in Medicaid but resembling them in the observed variables in Equation 2. Within each propensity score decile, each individual in Medicaid was then assigned a random draw from the non-Medicaid portion of their propensity-score matched distribution of out-of-pocket spending. Using draws from the actual distribution avoids making any parametric assumptions about the underlying spending distribution.

Finally, for each individual enrolled in Medicaid, we re-calculated their family resources as a percentage of FPL, after replacing their observed out-of-pocket spending (in Medicaid) with their random draw. What this means, in practice, is that some individuals experienced a rise in family resources while others a decline, though overall, the shift was towards lower family resources due to higher expected out-of-pocket spending in the non-Medicaid scenario.

To generate confidence intervals for this approach, we repeated 100 simulations with independent stochastic draws, and used the resulting distribution of MOOP and poverty rates to construct bootstrapped $95 \%$ confidence intervals.

III.B.4 Non-Stochastic Model: Propensity Score Matching with Fixed-Ratios of Out-of-Pocket Spending

\footnotetext{
${ }^{8}$ Disability status is based on the CPS question, "Do you have a health problem or a disability which prevents work or which limits the kind or amount of work?"
} 
This approach builds off the propensity score matching in the previous section, but instead of using a stochastic draw from the control distribution, we instead used a deterministic model that multiplied each Medicaid enrollee's actual MOOP by a fixed group-specific inflator. The inflator term was calculated for each propensity-score decile by eligibility group, based on the mean out-of-pocket spending by non-Medicaid individuals in that group divided by the mean out-of-pocket spending by Medicaid individuals in that same group. This yields the following equation for a Medicaid enrollee's counterfactual out-of-pocket spending:

$$
M O O P \_C F_{i}=M O O P \_M C_{i} *\left(\sum_{j} M O O P \_N M_{j} / n_{N}\right) /\left(\sum_{i} M O O P \_M C_{i} / n_{M}\right]
$$

where $M O O P \_C F_{i}$ is Medicaid enrollee $i$ 's counterfactual MOOP if they were not in Medicaid, $M O O P P_{-} M C_{i}$ is that person's actual MOOP in Medicaid, $M O O P_{-} N M_{j}$ is actual MOOP for person $j$ who is in the same propensity-eligibility group but is not in Medicaid, $n_{N}$ is the number of nonMedicaid individuals in the propensity-eligibility group, and $n_{M}$ is the number of Medicaid individuals in the propensity-eligibility group. In other words, we took each Medicaid enrollee's own out-of-pocket spending and inflated it by the same amount based on average MOOPs in their propensity-eligibility grouping. The average inflator for our sample was 2.65 , the median was 2.27 , with an interquartile range of 2.05 to 3.19 .

Current out-of-pocket spending in Medicaid is presumably correlated with the counterfactual of what a person would spend if they were not in Medicaid. Incorporating this information is an advantage of this approach over the stochastic method, in which a given person's actual spending bears no connection to their projected spending (since the latter is a random draw from a propensity score-matched distribution). However, the downside of this approach is that it reins in potential outliers in cost, since Medicaid - as a fairly comprehensive 
form of insurance - limits the possibility of catastrophically high out-of-pocket medical spending. This method also assigns those with $\$ 0$ in MOOP (36\% of all individuals in Medicaid in our sample) $\$ 0$ of MOOP in the counterfactual, even though having no out-of-pocket spending is less common among those with private coverage or no insurance at all $(11 \%$ and $32 \%$, respectively). For both of these reasons, we hypothesize that this approach will underestimate the poverty-reducing impact of Medicaid compared to a stochastic model.

\section{III.B.5 Heckman Sample Selection Model}

As a sensitivity analysis, we also tested a non-propensity score method that explicitly addresses the selection bias due to omitted variables. We constructed a Heckman sample selection model (Heckman 1979) that treated the counterfactual of non-Medicaid MOOP as a censored dependent variable, which is only observed for people not in Medicaid. The regression equation for this counterfactual is:

$$
M O O P_{-} C F_{i j j}=\beta_{0}+\beta_{1} X_{i}+\beta_{2} \text { Income }_{f}+\beta_{3} \text { State }_{j}+\varepsilon_{i j j}
$$

where $i$ indexes individuals, $f$ the family unit, and $j$ the state. $X_{i}$ is a vector of individual-level variables related to out-of-pocket medical spending, including age, self-reported health, educational attainment, citizenship, employment status, student status, disability, race, ethnicity, gender, and marital status. The vector Income $_{f}$ is defined as in Equation 2.

However, MOOP_CF $F_{i j}$ is only observed when $M c a i d_{i j j}=0$. We therefore model the following selection equation for the presence of Medicaid coverage:

$$
\text { Mcaid }_{i j j}=\beta_{0}+\beta_{1} X_{i}+\beta_{2} \text { Income }_{f}+\beta_{3} \text { ImputedEligible }_{i j j}+\beta_{4} \text { State }_{j}+\varepsilon_{i j j}
$$

where the independent variables are defined as above, and imputed Medicaid eligibility is added to the independent variables for Equation 4 to predict enrollment in Medicaid. 
The selection and regression equations were modeled separately for children, disabled adults, parents, childless adults, and the elderly. We then used fitted values from the Heckman model to predict $M O O P_{-} C F_{i}$ for those enrolled in Medicaid.

\section{III.C Institutionalized Populations}

Medicaid is the single largest payer for long-term care in the United States, but data sources describing the institutionalized population are more limited than for the rest of the population. To provide an estimate of the poverty-reducing impact of Medicaid among those living in institutions, we use the American Communities Survey (ACS), which unlike the CPS, includes institutionalized individuals in the sample. However, the ACS provides less detail on income than the CPS and no information on medical out-of-pocket spending. We adapt our approach to the ACS in a much more straightforward manner. Given that the predominant medical expense for most institutionalized individuals is that of long-term care, we focus exclusively on that outcome. Using national estimates on the annual cost of nursing home care, we assume that the full cost of this coverage would have to be paid out of pocket for individuals if they did not have Medicaid. Using the ACS' measure of family income, we subtract out the annual cost of nursing home care, and compare poverty rates with and without Medicaid.

This approach has several limitations. First, it assumes that all individuals in Medicaid would lack private long-term care insurance (LTCI) if they were not in Medicaid. While some such individuals might instead purchase LTCI, such coverage is quite rare (purchased by less than $3 \%$ of the population) and generally only affordable for individuals with greater incomes and assets than those eligible for Medicaid (Ujvaru 2012). Other limitations include the lack of data on acute care expenses, the ACS' limited income data that precludes a full application of the SPM poverty definition and instead uses an adapted form of the official poverty measure, and 
lack of income information on family members not living in the same institution. However, we are aware of no other data source that provides a nationally-representative sample of the U.S. institutionalized population with information on income and health insurance needed for this analysis. ${ }^{9}$ Subject to these limitations, our expectation is that this approach should provide at least a reasonable approximation of Medicaid's anti-poverty impact for those in long-term care.

\section{RESULTS}

\section{IV.A Propensity Score Matching for Medicaid Enrollment}

\section{IV.A.1 Summary Statistics by Propensity Score Decile}

Table I shows summary statistics for several selected propensity decile groups for children, comparing those who have Medicaid versus those who do not (similar tables for adults and the elderly are presented in Appendix Tables A.1 to A.4). The results show that the propensity score approach resulted in an effective matching of Medicaid and non-Medicaid enrollees with similar features on the observed variables. As expected, Medicaid enrollment was more common among racial and ethnic minorities; those with lower incomes, worse health, and less education; and those imputed to be eligible for Medicaid. ${ }^{10}$

\footnotetext{
${ }^{9}$ While the Health and Retirement Study (HRS) does include some individuals in long-term facilities, its original sample is limited to non-institutionalized individuals 50 years and over, and the only institutionalized respondents in the sample are those who enter facilities during the course of the study. This approach excludes those who enter facilities at younger ages, and significantly undersamples those over age 50 with long lengths of stay in institutionalized settings. The cross-sectional sampling of the ACS, in contrast, captures all such individuals for a nationally-representative sample of the institutionalized population.

${ }^{10}$ The individuals in the lowest propensity decile (indicating lowest likelihood of Medicaid coverage) who actually had Medicaid were atypical program beneficiaries, with high incomes and a large proportion reporting both Medicaid and private health insurance. This likely reflects two factors: first, the nature of the CPS insurance question - which asks about coverage at any time in the prior year and may capture individuals transitioning from one type of insurance to another; and second, Medicaid medically-needy provisions, in which individuals with significant health care costs can deduct those expenses to "spend down" their income and enroll in Medicaid, even though their baseline incomes are too high to be eligible Kaiser (2012). The Medicaid Medically Needy Program: Spending and Enrollment Update. Washington, D.C., Kaiser Family Foundation..
} 
Table I also includes estimates of actual insurance coverage and actual out-of-pocket medical spending (neither of which are part of the propensity score matching itself, since they are our outcomes of interest). In the lowest propensity score group (those unlikely to be in Medicaid), over $93 \%$ of non-Medicaid enrollees had private insurance and fewer than $5 \%$ were uninsured. In the highest propensity score decile, $38 \%$ had private coverage, $5 \%$ had Medicare coverage, and 56\% were uninsured. Out-of-pocket costs were higher among non-Medicaid enrollees in all propensity score groups, reflecting that Medicaid coverage has lower cost-sharing and premiums than private coverage and imposes less financial burden than being uninsured, even after taking into account the increase in utilization that likely occurs in Medicaid due to moral hazard. An advantage of our approach is that it does not require assigning any individual a particular counterfactual insurance type; instead, the propensity-score matched group implicitly represents the range of likely insurance outcomes for each group in the absence of Medicaid.

\section{IV.A.2 Predicted Insurance Status in the Absence of Medicaid}

Using the distribution of Medicaid enrollees in each propensity score group, we calculated a population-wide estimate of insurance coverage rates in the counterfactual scenario of no Medicaid (Table II). Overall, we estimate that in the absence of Medicaid, $42 \%$ of current Medicaid enrollees would have employer-sponsored private insurance, $5 \%$ would have nongroup private coverage, $12 \%$ would have Medicare, and $40 \%$ would be uninsured. By age and eligibility group, the risk of being uninsured ranged from $9 \%$ among the elderly ${ }^{11}$ to $50 \%$ among non-disabled adults. As expected, private insurance was the primary alternative for children and

\footnotetext{
${ }^{11}$ Some individuals aged 65 and over, primarily non-citizens without significant work histories in the U.S., are ineligible for Medicare coverage. Previous research demonstrates that these individuals are disproportionately represented in the Medicaid program. Gray, B. H., R. Scheinmann, et al. (2006). "Aging without Medicare? Evidence from New York City." Inquiry : a journal of medical care organization, provision and financing 43(3): 211-221.
} 
non-disabled adults. $40 \%$ of disabled adults ended up uninsured, with the remainder primarily covered by Medicare or private insurance. More than $90 \%$ of the elderly would have Medicare coverage. If anything, these numbers may overestimate coverage rates in the absence of Medicaid, since it is likely that even controlling for observable features, those currently in Medicaid may be less likely to have alternative insurance options than those not on Medicaid.

For this reason, we also included a sensitivity analysis in which the counterfactual was modeled based on propensity-matched controls excluding those with private coverage, which are presented in the next section.

\section{IV.B Estimates of the Poverty-Reducing Effects of Medicaid}

\section{IV.B.1 Preferred Specification, Stochastic and Non-Stochastic Versions}

Tables III and IV present estimates of the poverty-reducing effects of Medicaid for the stochastic and non-stochastic models, respectively.

In the stochastic model, eliminating Medicaid would lead to an increase in the population-wide poverty rate from $16.1 \%$ to $16.8 \%$, a net change of 0.7 percentage points $(95 \%$ CI $0.6,0.8)$ corresponding to an additional 2.12 million people living in poverty $(95 \%$ CI $1.94-$ 2.37M). Looking at the more restrictive cutoff of 50\% of FPL, the absence of Medicaid would increase extreme poverty from $5.4 \%$ to $5.8 \%$, corresponding to a net change of 1.35 million individuals $(95 \% \mathrm{CI} 1.16-1.51 \mathrm{M}) .{ }^{12}$ On a percentage-point basis, Medicaid's poverty reducing

\footnotetext{
${ }^{12}$ Note that we are unable to determine to what extent these two groups of people $-2.12 \mathrm{M}$ and $1.35 \mathrm{M}$ - overlap. There are three potential transitions using these cutoffs: 1) a transition from having family income above $100 \%$ FPL to somewhere between $50 \%$ and $100 \%$; 2 ) a transition from having family income above $100 \%$ FPL to an income below 50\%; and 3) a transition from having family income between 50 and $100 \%$ FPL to an income below $50 \%$. Our approach only allows us to identify those going from above to below the poverty line (transitions $1 \& 2$ ), and those going from above 50\% to below 50\% FPL (transitions $2 \& 3$ ). Since the stochastic draws do not bear a direct correspondence to a person's actual income, we cannot identify the individual transitions that are occurring, and instead only present results at the aggregate level.
} 
effects were greatest among adults with disabilities (2.2 percentage points) and children (1.0 percentage points).

In the non-stochastic propensity score model (Table IV), estimates of poverty reduction were somewhat lower: the poverty rate would increase from $16.1 \%$ to $16.6 \%$ in the absence of the Medicaid program (1.53 million additional people in poverty, 95\% CI 1.33M-1.72M). For extreme poverty, the estimated change was from $5.4 \%$ to $5.7 \%$ (1.00 million additional people, $0.83 \mathrm{M}$ to $1.16 \mathrm{M})$. While the number of people kept out of by poverty by Medicaid using the nonstochastic method was lower than in the stochastic model, the average income effects were comparable. In the stochastic model, the net effect of eliminating Medicaid would be to reduce family resources from $149 \%$ to $143 \%$ of FPL, due to an increase in MOOP per Medicaid enrollee of $\$ 495$ (from $\$ 376$ in Medicaid to $\$ 871$ without Medicaid). The analogous estimates from the non-stochastic model were similar - 144\% FPL, and change in MOOP of $\$ 443$.

Overall, these results demonstrate how the two methodologies differ in their ability to measure Medicaid's impact. While the methods produced similar average effects on Medicaid coverage, they produce quite different distributions of income. Stochastic methods lead to significantly higher rates of poverty - corresponding to the intuition that out-of-pocket medical spending is highly uncertain with wide variation, and protecting families against catastrophic costs is one of the ways Medicaid improves the economic well-being of beneficiaries. The nonstochastic model estimates a 0.5 percentage-point reduction due to Medicaid, while the stochastic model estimates a 0.7 percentage-point reduction, implying that the risk-protection aspect of Medicaid accounts for nearly one-third of the program's anti-poverty effect, with the remainder due to reduced average MOOP. 


\section{IV.B.2 Sensitivity Analyses}

When the baseline stochastic model was repeated excluding controls with private insurance (i.e. a zero crowd-out scenario), our estimates of poverty reduction actually decline, with a resulting national estimate of $0.3 \%$ (equivalent to 1.0 million individuals) and a reduction in average MOOP of $\$ 165$ per Medicaid beneficiary, as opposed to $\$ 495$ in our baseline model. This is because average MOOP is far lower for uninsured individuals compared to those with private insurance (roughly $\$ 1500$ less per year among non-elderly adults), which likely reflects both the impact of moral hazard inducing more utilization among the insured, and that some uninsured individuals may be less likely to consume health services in general than those with insurance. Together, these results suggest that part of the financial protection provided by Medicaid is not only based on covering the otherwise uninsured, but also by providing more generous coverage for some individuals who might otherwise obtain private coverage with onerous cost-sharing (so-called "underinsurance"). This latter effect - Medicaid protecting against the risk of underinsurance in private markets - is consistent with prior research (Magge, Cabral et al. 2013).

When we model poverty reduction using an adapted form of the official poverty measure, as opposed to the Supplemental Poverty Measure, we obtain fairly similar results. This approach requires subtracting out the simulated change in MOOP from the traditional measure of family income, and then dividing by the traditional poverty threshold for each family. This approach produces somewhat smaller reductions in poverty rates $(0.5 \%$ instead of $0.7 \%$, corresponding to 1.41M Americans rather than $2.12 \mathrm{M})$ and larger reductions in extreme poverty $(0.6 \%$ or $1.82 \mathrm{M}$, instead of $0.4 \%$ or $1.35 \mathrm{M})$. However, one must be cautious interpreting these results since they introduce a net change in MOOP as a factor in determining poverty rates even though the 
baseline MOOP is not part of the official poverty calculation.

Alternative models with different approaches to health status in the propensity score matching process produce similar results. A model in which the propensity score groupings were stratified for both eligibility group and health status (with the samples divided into those reporting "excellent," "very good," and "good," health, versus those in "fair" or "poor" health) led to very similar results as our preferred specification, with less than one-tenth of a percentage point greater estimates of poverty reduction $(2.16 \mathrm{M}$ fewer individuals in poverty and $1.36 \mathrm{M}$ fewer in extreme poverty). Excluding health status from the propensity matching entirely - thus exacerbating the potential omitted variable bias between Medicaid and non-Medicaid - only reduced our poverty reduction estimates a small amount, to $0.6 \%(1.98 \mathrm{M})$ fewer in poverty and $0.5 \%(1.23 \mathrm{M})$ in extreme poverty. Taken together, these findings suggest that while unobserved differences in health status may play a role in biasing our estimates downwards, at least based on self-reported health status, the apparent bias is fairly small.

\section{IV.C Heckman Selection Model Results}

Table V presents results from the Heckman model, using fitted values for out-of-pocket spending. The advantage of this approach is that it addresses the selection bias due to omitted variables that our propensity score method cannot capture. The disadvantage is that it does not capture the stochastic element necessary to model the risk of high-cost spending. ${ }^{13}$ In the Heckman model, the poverty rate without Medicaid increased from $16.1 \%$ to $16.9 \%(2.61$ million additional people, $95 \%$ CI $2.33-2.89 \mathrm{M}$ ), and extreme poverty rates would rise from $5.4 \%$

\footnotetext{
${ }^{13}$ Counterintuitively, the lack of a stochastic element in the Heckman model may bias our poverty estimates upwards, because the Heckman fitted values are pulled upwards by the positive skewness of the MOOP distribution. This is evident in examining the distribution of fitted values versus the actual distribution of MOOP. In the former, the median value is $\$ 419$, the $75^{\text {th }}$ percentile is $\$ 1277$, and the $95^{\text {th }}$ percentile is $\$ 2900$. In the latter, the median value is $\$ 100,75$ th percentile is $\$ 530$, and 95th is $\$ 4030$. Thus, the Heckman model appears to overestimate changes in MOOP in the center of the distribution, and underestimate them in the right tail of the distribution.
} 
to $5.7 \%$ (1.06 million additional people, $95 \%$ CI $0.86-1.26 \mathrm{M})$. These values show a significantly greater impact than the non-stochastic propensity score method, and a somewhat greater impact than in our preferred stochastic model (though the $95 \%$ confidence intervals for the latter are overlapping). These findings are consistent with our hypothesis that the selection bias in Medicaid enrollment leads to higher costs on average for Medicaid enrollees than would be expected based on their observable features, and provides an upper bound on our estimates for the poverty reduction attributable to Medicaid.

\section{IV.D Subgroup Analysis}

Using the stochastic model, we calculated changes in poverty rates and MOOP with our sample divided by race/ethnicity, gender, and Census region. These results are in Table VI. Poverty reductions due to Medicaid were greatest for blacks and Hispanics (1.5 and 1.2 percentage points, respectively), which was significantly higher than the poverty reduction among whites $(0.4$ percentage points; between group differences $p<0.001)$. Gender differences were much smaller, though still statistically significant, with Medicaid reducing poverty among women by 0.8 percentage points and 0.6 among men (between-group difference $p=0.026$ ). Both of these effects are consistent with the fact that minorities and women make up a disproportionate share of Medicaid enrollment (DeNavas-Walt, Proctor et al. 2011).

There were some differences in poverty reduction due to Medicaid across the four Census regions. Reductions in poverty were largest in the Northeast, where Medicaid eligibility criteria tend to be the most expansive and the covered benefits most generous (Arellano and Wolfe 2007; Heberlein, Brooks et al. 2011), though the differences were only statistically significant 
compared to the Midwest ( $\mathrm{p}=0.060$ for poverty, $\mathrm{p}=0.035$ for extreme poverty). Regional differences in reductions in MOOP due to Medicaid were not statistically significant.

\section{IV.E An Alternative Method for Valuing the Risk Reduction of Medicaid}

As an alternative method for measuring the economic benefit of Medicaid's impact on out-of-pocket spending that does not depend on the poverty rate, we follow the approach used by Finkelstein \& McKnight (2008). Using the expected utility formulation in Equation 1, and an assumption of constant relative risk aversion $(\mathrm{CRRA}=3)$, we calculated the average per-person income (family income divided by family size) within each propensity score decile. We then subtracted each person's actual MOOP, and integrated over the full survey-weighted population within each propensity score grouping to come up with estimated expected utility in two scenarios - with Medicaid coverage, and without Medicaid. We then calculated a risk premium $\left(\pi_{H}\right)$ for each scenario, following Finkelstein \& McKnight, defined as the change in baseline income the average person is willing to pay to fully insure against the random variable $M$ (medical out-of-pocket spending), according to the following equation:

$$
\mathrm{u}\left(\mathrm{Y}-\pi_{H}\right)=\int u(Y-M) f_{H}(M) d M
$$

We estimate this equation separately for those with Medicaid, and those without Medicaid. The difference in these risk premiums thus equals the economic value to the average person of moving from the non-Medicaid distribution of MOOP to the Medicaid distribution within their propensity score decile.

We estimate an average risk premium for non-Medicaid coverage of $\$ 4842$ per person, compared to a risk premium of $\$ 1968$ for Medicaid coverage. This difference implies an economic value of Medicaid coverage equal to $\$ 2874$ per person. This economic value ranges 
from $\$ 2123$ for children in Medicaid, to $\$ 3057$ for nondisabled adults, $\$ 3366$ for disabled adults, and $\$ 7177$ for elderly adults. Of course, these estimates are quite sensitive to the coefficient of risk aversion chosen; for $\mathrm{CRRA}=2$, indicating less risk aversion, the economic value falls from $\$ 2874$ to $\$ 1400$ per person. If $C R R A=0$, indicating risk neutrality, the value of Medicaid is $\$ 473$, quite close to the change in expected out-of-pocket spending in our baseline model $(\$ 495)$, as one would expect.

\section{IV.F Medicaid's Poverty-Reducing Effect Among Institutionalized Populations}

Table VII presents estimates from the American Communities Survey (ACS) on the Medicaid's poverty reducing impact, by Medicaid subgroup, of individuals living in institutionalized settings. Overall, $1.3 \%$ of the total U.S. population resided in institutional settings in 2010, equivalent to 4 millions individuals, $40 \%$ of whom had Medicaid coverage. Among these individuals, baseline poverty rates (even with Medicaid coverage) are extremely high - nearly $50 \%$ among the elderly, over $80 \%$ for non-elderly adults, and over $95 \%$ for children. Subtracting an average figure of $\$ 83,600$ a year (2010 inflation-adjusted dollars) in long-term care costs (Ujvaru 2012) from each person's income results in an increase in the overall poverty rate for institutionalized Americans by $12.2 \%$ (95\% CI 11.9\%, 12.6\%) and in the rate of extreme poverty by $21.6 \%(95 \%$ CI $21.2 \%, 22.0 \%) .{ }^{14}$ This corresponds to Medicaid keeping 490,000 institutionalized individuals out of poverty and 860,000 out of extreme poverty. As expected, the poverty-reducing impact in this population is concentrated among the elderly, though Medicaid kept an additional 160,000 disabled adults under age 65 out of extreme poverty.

\footnotetext{
${ }^{14}$ Analyses using smaller annual long-term care costs (e.g. $50 \%$ of the estimate cited above) produce very similar results, with poverty rates changed by $12.0 \%$ instead of $12.2 \%$.
} 


\section{DISCUSSION}

\section{V.A Comparing Medicaid to Other Poverty-Reducing Programs}

In our preferred model, we estimate that Medicaid reduces the poverty rate by 0.7 percentage points among non-institutionalized individuals, equivalent to 2.1 million children, adults, and elderly individuals nationally, with an additional half-million institutionalized individuals kept out of poverty. In Table VIII, we compare these estimates to other means-tested programs, focusing on the non-institutionalized population. For the other programs in this table, we calculated the net reduction in poverty rates attributable to each by subtracting the cash value of each program, as measured in the CPS' Supplemental Poverty Measure. Our numbers here match closely with official results reported recently by the Census Bureau (Short 2011). Overall, we find that Medicaid is the third largest poverty-reducing program in the country, behind EITC (1.9 percentage points) and SNAP (1.6 percentage points). The impact of Medicaid is equal to that of Temporary Assistance to Needy Families (TANF), school lunches, energy assistance, and Women, Infants, and Children (WIC) combined. With regard to extreme poverty, Medicaid is the most effective anti-poverty means-tested program among the elderly, whose poverty rates using the SPM are particularly affected by high out-of-pocket medical spending (Short 2011). If we add in the impact of Medicaid on the institutionalized population, the net effect on overall poverty rankings is unchanged, but Medicaid becomes the second-largest program in reducing the rate of Americans in extreme poverty.

The total number of people in these estimates represents a relatively small share of the number enrolled in Medicaid (2.6 million is roughly 5\% of the program's 2011 enrollment). However, there are several factors that shed light on why Medicaid did not affect the poverty status for the vast majority of beneficiaries. First, the CPS data source may lead to an 
underestimate of Medicaid's impact on poverty rates: the survey is known to undercount Medicaid enrollment compared to administrative files (by perhaps as much as 10\%), and this is also a problem - though to a lesser extent - in the ACS. If we adjust our estimate proportionately for a $10 \%$ undercount and use the upper estimate from the Heckman selection model, Medicaid might be keeping as many as 3.4 million Americans out of poverty. ${ }^{15}$

Aside from these data shortcomings, another key reason why Medicaid does not lift more people out of poverty is that, even with Medicaid coverage, $36 \%$ of beneficiaries in our CPS sample lived below $100 \%$ of FPL, another $18 \%$ lived above $200 \%$ of FPL, and the baseline poverty rate was over $70 \%$ among those in institutionalized settings. By the nature of using a net change in poverty rate as our primary outcome, resource gains that do not cross the FPL threshold of $100 \%$ do not affect this result. This is why we also include measures showing that Medicaid reduced average out-of-pocket spending by nearly $\$ 500$ per beneficiary, which for families living below the poverty level may represent more than a full month's income, as well as an estimate from an expected utility framework that Medicaid coverage provides over $\$ 2800$ worth of risk protection per beneficiary. Finally, while not measured in our data, Medicaid not only affects available family resources from disposable income, but also may affect family assets - protecting savings, limiting debt, and reducing the risk of personal bankruptcy. The Oregon Health Insurance Experiment showed some evidence for asset protection, with a reduced likelihood of unpaid medical bills sent to a collection agency in the year after obtaining Medicaid coverage (Finkelstein, Taubman et al. 2011).

In addition to these implications for understanding Medicaid's economic impact, our paper also makes a methodological contribution through the use of several alternative approaches

\footnotetext{
${ }^{15}$ The Heckman model estimates 2.61 million individuals were kept out of poverty by Medicaid. Increasing this by $10 \%$ to account for the survey undercount equals roughly 2.9 million. The addition of 500,000 individuals in institutions leads to a total of 3.4 million individuals kept out of poverty.
} 
for modeling non-Medicaid spending. Our results illustrate that a non-stochastic method of valuing Medicaid yields an in-kind transfer equal to approximately $\$ 500$ per person covered, but this may only account for two-thirds of Medicaid's overall population-level reduction in poverty, and less than one-sixth of the program's economic value as measured through an expected utility framework. The remaining benefit comes from risk protection, as Medicaid coverage prevents a relatively small percentage of families from experiencing very high out-of-pocket spending.

\section{V.B Policy Implications}

There are currently no serious policy proposals to eliminate Medicaid entirely, so in that sense, our empirical approach is largely a thought experiment. However, many states have cut or are considering reducing benefits and increasing cost-sharing (Heberlein, Brooks et al. 2011), and proposals to move to a block-grant approach to funding Medicaid could lead to major cutbacks in enrollment, particularly during periods of economic distress (Park and Broaddus 2012). Our results indicate that these changes might not only adversely affect health care access but also could create additional financial burdens on low-income beneficiaries and increase poverty rates in these states. Our subgroup analyses suggest that adverse financial consequences would disproportionately fall on minorities, the elderly, children, and those with disabilities.

Conversely, as states now debate whether to expand Medicaid under the Affordable Care Act to all qualifying residents with family incomes below $138 \%$ of FPL, ${ }^{16}$ our findings indicate significant economic gains for low-income populations in addition to potential impacts on health or access to care.

\footnotetext{
${ }^{16}$ The Supreme Court ruled in June 2012 that it would be unconstitutional for the Secretary of Health and Human Services to withhold all federal Medicaid funding from states that choose not to participate in the Affordable Care Act's Medicaid expansion. The practical impact of this ruling was to make the Medicaid expansion a state option.
} 
Nonetheless, an important caveat is that our analysis is essentially a partial equilibrium approach, modeling a simple on-versus-off scenario for the Medicaid program. Of course, in the absence of Medicaid, a whole host of second-order general equilibrium effects would become relevant, the most important of which would be changes in other safety net alternatives and forms of uncompensated care for the poor, as well as potential fundamental changes in private insurance offer and take-up rates. Individuals shifting from Medicaid to employer-sponsored insurance would face not only greater cost-sharing and premiums, but also potentially a downward shift in wages as a compensating differential for their health insurance (Summers 1989) - though research suggests that lower-wage workers like those in Medicaid are least likely to bear the full incidence of employer-sponsored coverage (Sommers 2005). Finally, Medicaid may have stimulating effects on the economy beyond just those who are enrolled in the program, as suggested by studies of Medicaid spending under the American Recovery and Reinvestment Act of 2009 (Chodorow-Reich, Feiveson et al. 2012). Our approach implicitly takes into account the insurance transitions that would likely occur in the absence of Medicaid, by looking at the coverage patterns of propensity-score matched individuals not in Medicaid. But we did not attempt to model the larger general equilibrium consequences of eliminating the program.

Extrapolating from our results to what might occur in the face of the Affordable Care Act's large Medicaid expansion slated for 2014 is also complicated by general equilibrium considerations. One of the most commonly-cited concerns with respect to this expansion is whether there will be adequate provider capacity to treat the additional increase in Medicaid enrollment, or whether overall utilization will be constrained based on physician supply (White 2012). However, even if total utilization among low-income individuals does not increase under the Affordable Care Act, the out-of-pocket portion of spending almost certainly would decline 
among the 10-20 million individuals expected to enroll in Medicaid under this provision (Elmendorf 2012). Furthermore, unlike some current program beneficiaries (especially in CHIP), newly-eligible individuals under the Affordable Care Act will be almost exclusively poor or near-poor individuals, many of whom are childless adults not currently eligible for the program, regardless of how low their incomes are. This implies that the poverty-reducing impact of Medicaid will become increasingly targeted starting in 2014 on those who might most benefit from increased risk protection and reduced out-of-pocket medical spending.

\section{V.C Conclusion}

When out-of-pocket medical expenses are taken into account in defining the poverty rate, Medicaid and CHIP play a significant role in poverty reduction for millions of Americans, in all age groups. Beyond the program's primary benefit of improved access to care and health, we find that Medicaid has significant poverty-reducing effects of a similar order of magnitude as other dedicated anti-poverty government programs. The program's financial impact is most concentrated among people with disabilities, children, and elderly adults, and among racial and ethnic minorities. Eligibility reductions or benefit cutbacks in Medicaid are likely to worsen the economic circumstances of many low-income Americans, whereas plans to expand Medicaid eligibility in 2014 under the Affordable Care Act could produce significant reductions in poverty, especially for childless adults who generally are ineligible for Medicaid under current law. 


\section{REFERENCES}

Arellano, A. B. R. and S. M. Wolfe (2007). Unsettling scores: a ranking of state Medicaid programs. Washington, DC, Public Citizen.

Blumberg, L. J., L. Dubay, et al. (2000). "Did the Medicaid expansions for children displace private insurance? An analysis using the SIPP." Journal of health economics 19(1): 3360.

Burtless, G. and S. Siegel (2001). Medical Spending, Health Insurance, and Measurement of American Poverty. Washington, DC, Brookings Institution.

Busch, S. H. and N. Duchovny (2005). "Family coverage expansions: impact on insurance coverage and health care utilization of parents." J Health Econ 24(5): 876-890.

Call, K. T., G. Davidson, et al. (2008). "Medicaid undercount and bias to estimates of uninsurance: new estimates and existing evidence." Health Serv Res 43(3): 901-914.

Caswell, K. J. and B. O'Hara (2010). Medical Out-of-Pocket Expenses, Poverty, and the Uninsured. SEHSD Working Paper 2010-17. Washington, DC, U.S. Census Bureau.

Chodorow-Reich, G., L. Feiveson, et al. (2012). "Does State Fiscal Relief During Recessions Increase Employment? Evidence from the American Recovery and Reinvestment Act." American Economic Journal: Economic Policy 4(3): 118-145.

Citro, C. F. and R. T. Michael (1995). Measuring Poverty: A New Approach. Washington, DC, National Academy Press.

Currie, J. and J. Gruber (1996). "Health insurance eligibility, utilization of medical care and child health." Quarterly Journal of Economics 111(2): 431-466.

Currie, J. and J. Gruber (1996). "Saving Babies: The Efficacy and Cost of Recent Expansions of Medicaid Eligibility for Pregnant Women." Journal of Political Economy 104(6): 12631296.

Cutler, D. and J. Gruber (1996). "Does Public Insurance Crowd Out Private Insurance?" The Quarterly Journal of Economics 11(1): 391-460.

Dehejia, R. H. and S. Wahba (2002). "Propensity-Score Matching Methods for Nonexperimental Causal Studies." Review of Economics and Statistics 84(1): 151-161.

DeNavas-Walt, C., B. Proctor, et al. (2011). Income, poverty, and health insurance coverage in the United States: 2010. Washington, DC, U.S. Census Bureau.

Dubay, L., J. Holahan, et al. (2007). "The Uninsured and the Affordability of Health Insurance Coverage." Health Affairs 26(1): w22-w30.

Elmendorf, D. W. (2012). Estimates for the Insurance Coverage Provisions of the Affordable Care Act Updated for the Recent Supreme Court Decision. Washington DC, Congressional Budget Office.

Finkelstein, A. and R. McKnight (2008). "What did Medicare do? The initial impact of Medicare on mortality and out of pocket medical spending." Journal of Public Economics 92: 16441668.

Finkelstein, A., S. Taubman, et al. (2011). The Oregon health insurance experiment: evidence from the first year. Cambridge, MA, National Bureau of Economic Research.

Gilleskie, D. B. (1998). "A dynamic stochastic model of medical care use and work absence." Econometrica 66(1): 1-45.

Gilleskie, D. B. and T. A. Mroz (2004). "A flexible approach for estimating the effects of covariates on health expenditures." Journal of health economics 23: 391-418. 
Gray, B. H., R. Scheinmann, et al. (2006). "Aging without Medicare? Evidence from New York City." Inquiry : a journal of medical care organization, provision and financing 43(3): 211-221.

Gruber, J. and K. Simon (2008). "Crowd-out 10 years later: have recent public insurance expansions crowded out private health insurance?" Journal of health economics 27(2): 201-217.

Hamersma, S. and M. Kim (2013). "Participation and crowd out: Assessing the effects of parental Medicaid expansions." Journal of health economics 32: 160-171.

Heberlein, M., T. Brooks, et al. (2011). Holding Steady, Looking Ahead: Annual Findings Of A 50-State Survey Of Eligibility Rules, Enrollment and Renewal Procedures, And Cost Sharing Practices in Medicaid and CHIP, 2010-2011. Washington, D.C., Kaiser Family Foundation.

Heckman, J. (1979). "Sample selection bias as a specification error." Econometrica 47: 153-161. Kaiser (2009). Where are states today? Medicaid and state-funded coverage eligibility levels for low-income adults. Washington, D.C., Kaiser Family Foundation.

Kaiser (2010). Medicaid financial eligibility: primary pathways for the elderly and people with disabilities. Washington, D.C., Kaiser Family Foundation.

Kaiser (2012). The Medicaid Medically Needy Program: Spending and Enrollment Update. Washington, D.C., Kaiser Family Foundation.

Kenney, G. M., V. Lynch, et al. (2011). Gains for Children: Increased Participation in Medicaid and CHIP in 2009, Urban Institute / Robert Wood Johnson Foundation.

Kronebusch, K. and B. Elbel (2004). "Enrolling children in public insurance: SCHIP, Medicaid, and state implementation." Journal of health politics, policy and law 29(3): 451-489.

Long, S. K., T. Coughlin, et al. (2005). "How well does Medicaid work in improving access to care?" Health Serv Res 40(1): 39-58.

Magge, H., H. J. Cabral, et al. (2013). "Prevalence and Predictors of Underinsurance Among Low-Income Adults." Journal of general internal medicine.

McClellan, M. and J. Skinner (2006). "The incidence of Medicare." Journal of Public Economics 90: $257-276$.

O'Brien, E. (2005). Long-term care: Understanding Medicaid's Role for the Elderly and Disabled. Washington, DC, Kaiser Family Foundation.

Orszag, P. R. (2007). Estimates of the Number of Uninsured Children Who Are Eligible for Medicaid or SCHIP. Washington, D.C., Congressional Budget Office.

Park, E. and M. Broaddus (2012). What if Chairman Ryan's Medicaid Block Grant Had Taken Effect in 2001? Washington, DC, Center on Budget and Policy Priorities.

Remler, D. K. and S. A. Glied (2003). "What other programs can teach us: increasing participation in health insurance programs." American journal of public health 93(1): $67-$ 74.

Renwick, T. (2009). Alternative Geographic Adjustments of U.S. Poverty Thresholds: Impact on State Poverty Rates. Washington, DC, U.S. Census Bureau.

Ross, D. C., M. Jarlenski, et al. (2009). A Foundation for Health Reform. Washington, D.C., Kaiser Family Foundation.

Ruggles, P. (1995). Drawing the Line: Alternative Poverty Measures and Their Implications for Public Policy. Washington, DC, The Urban Institute Press.

Short, K. (2011). The Research Supplemental Poverty Measure: 2010. Washington, DC, U.S. Census Bureau. 
Sommers, B. D. (2005). "Who really pays for health insurance? The incidence of employerprovided health insurance with sticky nominal wages." International journal of health care finance and economics 5(1): 89-118.

Sommers, B. D. (2009). "Loss of health insurance among non-elderly adults in Medicaid." J Gen Intern Med 24(1): 1-7.

Sommers, B. D., K. Baicker, et al. (2012). "Mortality and Access to Care among Adults after State Medicaid Expansions." The New England journal of medicine.

Sommers, B. D., M. R. Tomasi, et al. (2012). "Reasons for the wide variation in medicaid participation rates among States hold lessons for coverage expansion in 2014." Health affairs 31(5): 909-919.

Summers, L. H. (1989). "Some Simple Economics of Mandated Benefits." American Economic Review 79(2): 177-183.

Swartz, K. (1986). "Interpreting the estimates from four national surveys of the number of people without health insurance." J Econ Soc Meas 14(3): 233-242.

Thorpe, K. E. and C. S. Florence (1998). "Health insurance among children: the role of expanded Medicaid coverage." Inquiry : a journal of medical care organization, provision and financing 35(4): 369-379.

Truffer, C. J., J. D. Klemm, et al. (2012). 2011 Actuarial Report on the Financial Outlook for Medicaid. Baltimore, MD, Office of the Actuary, Centers for Medicare and Medicaid Services.

Ujvaru, K. (2012). Long-Term Care Insurance: 2012 Update. Washington, DC, AARP Public Policy Institute.

van der Klaauw, W. and K. I. Wolpin (2008). "Social security and the retirement and savings behavior of low-income households." Journal of Econometrics 145: 21-42.

Weicher, J. C. (1999). "Some income-measurement issues and their policy implications." American Economic Review 89(2): 29-33.

Weissman, J. S., R. Stern, et al. (1991). "Delayed access to health care: risk factors, reasons, and consequences." Ann Intern Med 114(4): 325-331.

White, C. (2012). "A comparison of two approaches to increasing access to care: Expanding coverage versus increasing physician fees." Health services research Epub ahead of print.

Ziliak, J. P. (2011). Recent Developments in Antipoverty Policies in the United States. Madison, WI, Institute for Research on Poverty. 
Table I:

Summary Statistics for Selected Propensity Score Deciles of Medicaid Coverage, Among Children (0-18)

\begin{tabular}{|c|c|c|c|c|c|c|}
\hline \multirow[t]{2}{*}{ Variable } & \multicolumn{2}{|c|}{$\begin{array}{l}\text { Propensity Score Decile=1 } \\
\text { (Low likelihood Medicaid) }\end{array}$} & \multicolumn{2}{|c|}{$\begin{array}{c}\text { Propensity Score Decile=5 } \\
\text { (Medium likelihood Medicaid) }\end{array}$} & \multicolumn{2}{|c|}{$\begin{array}{l}\text { Propensity Score Decile=10 } \\
\text { (High likelihood Medicaid) }\end{array}$} \\
\hline & Not in Medicaid & Medicaid & Not in Medicaid & Medicaid & Not in Medicaid & Medicaid \\
\hline Age & 10.1 & 10.2 & 10.0 & 9.1 & 6.4 & 6.4 \\
\hline Male & $50.8 \%$ & $53.3 \%$ & $52.2 \%$ & $51.2 \%$ & $55.8 \%$ & $54.5 \%$ \\
\hline White & $87.2 \%$ & $83.9 \%$ & $75.2 \%$ & $74.3 \%$ & $56.0 \%$ & $48.4 \%$ \\
\hline Black & $3.9 \%$ & $6.5 \%$ & $14.1 \%$ & $13.6 \%$ & $36.8 \%$ & $42.3 \%$ \\
\hline Latino & $8.5 \%$ & $13.7 \%$ & $31.9 \%$ & $29.9 \%$ & $39.3 \%$ & $36.4 \%$ \\
\hline Parent Education & & & & & & \\
\hline$-<12^{\text {th }}$ Grade & $0.2 \%$ & $0.8 \%$ & $7.1 \%$ & $6.5 \%$ & $23.7 \%$ & $28.5 \%$ \\
\hline -High School & $22.7 \%$ & $31.8 \%$ & $64.8 \%$ & $66.8 \%$ & $73.6 \%$ & $68.2 \%$ \\
\hline -College Graduate & $77.1 \%$ & $67.3 \%$ & $28.0 \%$ & $26.8 \%$ & $2.7 \%$ & $3.3 \%$ \\
\hline Family Income & & & & & & \\
\hline (\%FPL) & $564 \%$ & $441 \%$ & $110 \%$ & $116 \%$ & $59 \%$ & $52 \%$ \\
\hline Non-Citizen & $1.9 \%$ & $3.9 \%$ & $7.0 \%$ & $4.6 \%$ & $0.5 \%$ & $0.0 \%$ \\
\hline Health & & & & & & \\
\hline -Excellent & $64.5 \%$ & $54.0 \%$ & $47.7 \%$ & $47.0 \%$ & $18.0 \%$ & $18.3 \%$ \\
\hline -Very Good & $27.6 \%$ & $32.6 \%$ & $29.6 \%$ & $32.3 \%$ & $27.4 \%$ & $28.1 \%$ \\
\hline -Good & $7.8 \%$ & $12.3 \%$ & $20.0 \%$ & $18.0 \%$ & $38.5 \%$ & $38.8 \%$ \\
\hline -Fair/Poor & $0.2 \%$ & $1.0 \%$ & $2.7 \%$ & $2.7 \%$ & $16.0 \%$ & $14.8 \%$ \\
\hline Imputed Eligible & $2.3 \%$ & $7.0 \%$ & $99.9 \%$ & $99.7 \%$ & $100.0 \%$ & $100.0 \%$ \\
\hline Actual Insurance* & & & & & & \\
\hline -Medicaid & $0.0 \%$ & $100.0 \%$ & $0.0 \%$ & $100.0 \%$ & $0.0 \%$ & $100.0 \%$ \\
\hline -Private Insurance & $93.6 \%$ & $49.5 \%$ & $56.8 \%$ & $14.5 \%$ & $37.5 \%$ & $6.4 \%$ \\
\hline -Medicare & $0.1 \%$ & $1.5 \%$ & $1.1 \%$ & $1.3 \%$ & $4.7 \%$ & $1.2 \%$ \\
\hline -Uninsured & $4.8 \%$ & $0.0 \%$ & $38.7 \%$ & $0.0 \%$ & $56.0 \%$ & $0.0 \%$ \\
\hline $\begin{array}{l}\text { Out-of-pocket } \\
\text { medical spending }\end{array}$ & $\$ 413$ & $\$ 198$ & $\$ 302$ & $\$ 95$ & $\$ 287$ & $\$ 134$ \\
\hline Cell Size & $N=24,195$ & $N=2026$ & $N=1651$ & $N=2026$ & $N=405$ & $N=2026$ \\
\hline
\end{tabular}

Note:

* Individuals may report multiple forms of insurance in the Current Population Survey, so numbers sum to more than $100 \%$. From authors' analysis of the 2011 Current Population Survey. 
Table II:

Predicted Insurance Coverage for Medicaid Enrollees in the Absence of Medicaid

\begin{tabular}{|l|c|c|c|c|c|}
\hline Group & $\begin{array}{l}\text { Employer- } \\
\text { Sponsored } \\
\text { Insurance }\end{array}$ & $\begin{array}{l}\text { Non-Group } \\
\text { Private } \\
\text { Insurance }\end{array}$ & Medicare & $\begin{array}{l}\text { Other } \\
\text { Insurance }\end{array}$ & Uninsured \\
\hline Children 0-18 & $51.5 \%$ & $5.1 \%$ & $2.1 \%$ & $2.4 \%$ & $39.0 \%$ \\
\hline Nondisabled Adults 19-64 & $41.4 \%$ & $4.9 \%$ & $2.3 \%$ & $1.9 \%$ & $49.6 \%$ \\
\hline Disabled Adults 19-64 & $22.0 \%$ & $3.3 \%$ & $30.6 \%$ & $4.0 \%$ & $40.1 \%$ \\
\hline Elderly & $3.2 \%$ & $1.0 \%$ & $87.2 \%$ & $0.1 \%$ & $8.5 \%$ \\
\hline Total & $\mathbf{4 2 . 0 \%}$ & $\mathbf{4 . 5 \%}$ & $\mathbf{1 1 . 7 \%}$ & $\mathbf{2 . 3 \%}$ & $\mathbf{3 9 . 5 \%}$ \\
\hline
\end{tabular}

Note:

$\mathrm{N}=34,304$. From authors' analysis of the 2011 Current Population Survey.

Individuals may report multiple forms of insurance in the Current Population Survey. For these estimates of alternative coverage, we exclude those reporting both Medicaid and private insurance at baseline. We also use a health insurance hierarchy as follows, in which we assign each person a single form of primary coverage based on the following priority order: Medicare, employer-sponsored insurance (ESI), non-group private insurance, other insurance, or uninsured. 
Table III:

Poverty Reduction Attributable To Medicaid, Using a Stochastic Model of Out-of-Pocket Medical Care Spending

\begin{tabular}{|c|c|c|c|c|c|c|}
\hline Outcome & $\begin{array}{l}\text { Status Quo } \\
\text { (with } \\
\text { Medicaid) }\end{array}$ & $\begin{array}{l}\text { Counterfactual } \\
\text { without } \\
\text { Medicaid }\end{array}$ & $\begin{array}{l}\text { Difference } \\
(\%)\end{array}$ & $95 \%$ CI & $\begin{array}{l}\text { Difference } \\
\text { (Persons) }\end{array}$ & $95 \% \mathrm{CI}$ \\
\hline \multicolumn{7}{|l|}{$\begin{array}{l}\text { Poverty Rate }(<100 \% \\
\text { FPL })\end{array}$} \\
\hline - Children 0-18 & $18.4 \%$ & $19.4 \%$ & $1.0 \% * *$ & $0.9,1.2 \%$ & $0.81 \mathrm{M}$ & $\begin{array}{l}0.69 \\
0.95 \mathrm{M}\end{array}$ \\
\hline $\begin{array}{l}\text { - Nondisabled Adults } \\
19-64\end{array}$ & $13.7 \%$ & $14.1 \%$ & $0.4 \% * *$ & $0.4,0.5 \%$ & $0.69 \mathrm{M}$ & $\begin{array}{l}0.62 \\
0.80 \mathrm{M}\end{array}$ \\
\hline - Disabled Adults 19-64 & $30.6 \%$ & $32.8 \%$ & $2.2 \% * *$ & $1.8,2.6 \%$ & $0.34 \mathrm{M}$ & $\begin{array}{l}0.28 \\
0.40 \mathrm{M}\end{array}$ \\
\hline - Elderly & $15.9 \%$ & $16.6 \%$ & $0.7 \% * *$ & $0.6,0.8 \%$ & $0.27 \mathrm{M}$ & $\begin{array}{l}0.22 \\
0.33 \mathrm{M}\end{array}$ \\
\hline Total & $16.1 \%$ & $16.8 \%$ & $0.7 \% * *$ & $0.6,0.8 \%$ & $2.12 \mathrm{M}$ & $\begin{array}{l}1.94 \\
2.37 \mathrm{M}\end{array}$ \\
\hline \multicolumn{7}{|l|}{$\begin{array}{l}\text { Extreme Poverty Rate } \\
(<50 \% \text { FPL })\end{array}$} \\
\hline - Children 0-18 & $5.5 \%$ & $6.1 \%$ & $0.6 \% * *$ & $0.5,0.7 \%$ & $0.48 \mathrm{M}$ & $\begin{array}{l}0.40 \\
0.57 \mathrm{M}\end{array}$ \\
\hline $\begin{array}{l}\text { - Nondisabled Adults } \\
19-64\end{array}$ & $5.1 \%$ & $5.3 \%$ & $0.3 \% * *$ & $0.2,0.3 \%$ & $0.43 \mathrm{M}$ & $\begin{array}{l}0.36 \\
0.50 \mathrm{M}\end{array}$ \\
\hline - Disabled Adults 19-64 & $9.9 \%$ & $11.9 \%$ & $1.9 \% * *$ & $1.6,2.3 \%$ & $0.30 \mathrm{M}$ & $\begin{array}{l}0.24 \\
0.36 \mathrm{M}\end{array}$ \\
\hline - Elderly & $4.7 \%$ & $5.0 \%$ & $0.4 \% * *$ & $0.3,0.5 \%$ & $0.13 \mathrm{M}$ & $\begin{array}{l}0.10 \\
0.13 \mathrm{M}\end{array}$ \\
\hline Total & $5.4 \%$ & $5.8 \%$ & $0.4 \% * *$ & $0.4,0.5 \%$ & $1.35 \mathrm{M}$ & $\begin{array}{l}1.16 \\
1.51 \mathrm{M}\end{array}$ \\
\hline \multicolumn{7}{|l|}{ For Individuals in } \\
\hline $\begin{array}{l}\text { Family Income, } \% \text { of } \\
\text { FPL }\end{array}$ & $149 \%$ & $143 \%$ & $-6.0 \% * *$ & $\begin{array}{l}-6.6 \\
-5.6 \%\end{array}$ & $\mathrm{~N} / \mathrm{A}$ & \\
\hline $\begin{array}{l}\text { Per capita medical out- } \\
\text { of-pocket spending }\end{array}$ & $\$ 376$ & $\$ 871$ & $\$ 495^{* *}$ & $\begin{array}{l}\$ 453 \\
\$ 540\end{array}$ & N/A & \\
\hline
\end{tabular}

$* * \mathrm{p}<0.01, * \mathrm{p}<0.05$.

$95 \%$ confidence intervals (CI) are based on bootstrapped standard errors.

Numbers may not sum precisely due to rounding. $N=204,983$. From authors' analysis of the 2011 Current Population Survey. 
Table IV:

Poverty Reduction Attributable To Medicaid, Using a Non-Stochastic Propensity Score Model of Out-of-Pocket Medical Care Spending

\begin{tabular}{|c|c|c|c|c|c|c|}
\hline Outcome & $\begin{array}{l}\text { Status Quo } \\
\text { (with } \\
\text { Medicaid) }\end{array}$ & $\begin{array}{l}\text { Counterfactual } \\
\text { without Medicaid }\end{array}$ & $\begin{array}{l}\text { Difference } \\
(\%)\end{array}$ & 95\% CI & $\begin{array}{l}\text { Difference } \\
\text { (Persons) }\end{array}$ & $\begin{array}{l}95 \% \\
\text { CI }\end{array}$ \\
\hline Poverty Rate $(<100 \%$ FPL $)$ & & & & & & \\
\hline - Children 0-18 & $18.4 \%$ & $19.1 \%$ & $0.7 \% * * *$ & $\begin{array}{l}0.6 \\
0.8 \%\end{array}$ & $0.55 \mathrm{M}$ & $\begin{array}{l}0.45 \\
0.65 \mathrm{M}\end{array}$ \\
\hline - Nondisabled Adults 19-64 & $13.7 \%$ & $14.0 \%$ & $0.3 \% * * *$ & $\begin{array}{l}0.2 \\
0.4 \%\end{array}$ & $0.50 \mathrm{M}$ & $\begin{array}{l}0.41 \\
0.58 \mathrm{M}\end{array}$ \\
\hline - Disabled Adults 19-64 & $30.6 \%$ & $32.3 \%$ & $1.7 \% * * *$ & $\begin{array}{l}1.3 \\
2.0 \%\end{array}$ & $0.26 \mathrm{M}$ & $\begin{array}{l}0.21 \\
0.31 \mathrm{M}\end{array}$ \\
\hline - Elderly & $15.9 \%$ & $16.5 \%$ & $0.6 \% * * *$ & $\begin{array}{l}0.5 \\
0.7 \%\end{array}$ & $0.22 \mathrm{M}$ & $\begin{array}{l}0.18 \\
0.27 \mathrm{M}\end{array}$ \\
\hline Total & $16.1 \%$ & $16.6 \%$ & $0.5 \% * * *$ & $\begin{array}{l}0.4 \\
0.6 \%\end{array}$ & $1.53 \mathrm{M}$ & $\begin{array}{l}1.33 \\
1.72 M\end{array}$ \\
\hline \multicolumn{7}{|l|}{$\begin{array}{l}\text { Extreme Poverty Rate }(<50 \% \\
\text { FPL })\end{array}$} \\
\hline - Children $0-18$ & $5.5 \%$ & $5.9 \%$ & $0.5 \% * * *$ & $\begin{array}{l}0.4 \\
0.6 \%\end{array}$ & $0.37 \mathrm{M}$ & $\begin{array}{l}0.28 \\
0.45 \mathrm{M}\end{array}$ \\
\hline - Nondisabled Adults 19-64 & $5.1 \%$ & $5.2 \%$ & $0.2 \% * * *$ & $\begin{array}{l}0.1 \\
0.2 \%\end{array}$ & $0.31 \mathrm{M}$ & $\begin{array}{l}0.24 \\
0.37 \mathrm{M}\end{array}$ \\
\hline - Disabled Adults 19-64 & $9.9 \%$ & $11.3 \%$ & $1.4 \% * * *$ & $\begin{array}{l}1.1 \\
1.7 \%\end{array}$ & $0.21 \mathrm{M}$ & $\begin{array}{l}0.17 \\
0.26 \mathrm{M}\end{array}$ \\
\hline - Elderly & $4.7 \%$ & $5.0 \%$ & $0.3 \% * * *$ & $\begin{array}{l}0.2 \\
0.4 \%\end{array}$ & $0.12 \mathrm{M}$ & $\begin{array}{l}0.08 \\
0.15 \mathrm{M}\end{array}$ \\
\hline Total & $5.4 \%$ & $5.7 \%$ & $0.3 \% * * *$ & $\begin{array}{l}0.3 \\
0.4 \%\end{array}$ & $1.00 \mathrm{M}$ & $\begin{array}{l}0.83 \\
1.16 M\end{array}$ \\
\hline \multicolumn{7}{|l|}{ For Individuals in Medicaid } \\
\hline$\overline{\text { Family Income, } \% \text { of FPL }}$ & $149 \%$ & $144 \%$ & $-5 \% * * *$ & $\begin{array}{l}-5.4 \\
-4.7 \%\end{array}$ & N/A & \\
\hline $\begin{array}{l}\text { Per capita medical out-of-pocket } \\
\text { spending }\end{array}$ & $\$ 376$ & $\$ 819$ & $\$ 443 * * *$ & $\begin{array}{l}\$ 415 \\
\$ 470\end{array}$ & N/A & \\
\hline
\end{tabular}

$* * * \mathrm{p}<0.001, * * \mathrm{p}<0.01,{ }^{*} \mathrm{p}<0.05$

Numbers may not sum precisely due to rounding. $N=204,983$. From authors' analysis of the 2011 Current Population Survey. 


\section{Table V:}

\section{Poverty Reduction Attributable To Medicaid, Using a Heckman Sample Selection Model for Out-of-Pocket Medical Care Spending}

\begin{tabular}{|c|c|c|c|c|c|c|}
\hline Outcome & $\begin{array}{l}\text { Status Quo } \\
\text { (with } \\
\text { Medicaid) }\end{array}$ & $\begin{array}{l}\text { Counterfactual } \\
\text { without Medicaid }\end{array}$ & $\begin{array}{l}\text { Difference } \\
(\%)\end{array}$ & $\begin{array}{l}95 \% \\
\text { CI }\end{array}$ & $\begin{array}{l}\text { Difference } \\
\text { (Persons) }\end{array}$ & $\begin{array}{l}95 \% \\
\text { CI }\end{array}$ \\
\hline Poverty Rate $(<100 \%$ FPL $)$ & & & & & & \\
\hline - Children 0-18 & $18.4 \%$ & $19.4 \%$ & $1.1 \% * * *$ & $\begin{array}{l}0.9 \\
1.2 \%\end{array}$ & $0.85 \mathrm{M}$ & $\begin{array}{l}0.70 \\
1.0 \mathrm{M}\end{array}$ \\
\hline - Nondisabled Adults 19-64 & $13.7 \%$ & $14.1 \%$ & $0.4 \% * * *$ & $\begin{array}{l}0.3 \\
0.5 \%\end{array}$ & $0.69 \mathrm{M}$ & $\begin{array}{l}0.57 \\
0.80 \mathrm{M}\end{array}$ \\
\hline - Disabled Adults 19-64 & $30.6 \%$ & $34.8 \%$ & $4.2 \% * * *$ & $\begin{array}{l}3.6, \\
4.7 \%\end{array}$ & $0.64 \mathrm{M}$ & $\begin{array}{l}0.55 \\
0.72 \mathrm{M}\end{array}$ \\
\hline - Elderly & $15.9 \%$ & $17.0 \%$ & $1.1 \% * * *$ & $\begin{array}{l}0.9 \\
1.3 \%\end{array}$ & $0.44 \mathrm{M}$ & $\begin{array}{l}0.37 \\
0.51 \mathrm{M}\end{array}$ \\
\hline Total & $16.1 \%$ & $16.9 \%$ & $0.9 \% * * *$ & $\begin{array}{l}0.8 \\
0.9 \%\end{array}$ & $2.61 \mathrm{M}$ & $\begin{array}{l}2.33 \\
2.89 \mathrm{M}\end{array}$ \\
\hline \multicolumn{7}{|l|}{$\begin{array}{l}\text { Extreme Poverty Rate }(<50 \% \\
\text { FPL })\end{array}$} \\
\hline - Children 0-18 & $5.5 \%$ & $5.9 \%$ & $0.5 \% * * *$ & $\begin{array}{l}0.3 \\
0.6 \%\end{array}$ & $0.37 \mathrm{M}$ & $\begin{array}{l}0.27 \\
0.47 \mathrm{M}\end{array}$ \\
\hline - Nondisabled Adults 19-64 & $5.1 \%$ & $5.2 \%$ & $0.2 \% * * *$ & $\begin{array}{l}0.1 \\
0.2 \%\end{array}$ & $0.30 \mathrm{M}$ & $\begin{array}{l}0.22 \\
0.38 \mathrm{M}\end{array}$ \\
\hline - Disabled Adults 19-64 & $9.9 \%$ & $11.6 \%$ & $1.8 \% * * *$ & $\begin{array}{l}1.4, \\
2.3 \%\end{array}$ & $0.28 \mathrm{M}$ & $\begin{array}{l}0.21 \\
0.36 \mathrm{M}\end{array}$ \\
\hline - Elderly & $4.7 \%$ & $4.9 \%$ & $0.3 \% * * *$ & $\begin{array}{l}0.1 \\
0.4 \%\end{array}$ & $0.10 \mathrm{M}$ & $\begin{array}{l}0.06 \\
0.14 \mathrm{M}\end{array}$ \\
\hline Total & $5.4 \%$ & $5.7 \%$ & $0.3 \% * * *$ & $\begin{array}{l}0.3 \\
0.4 \%\end{array}$ & $1.06 \mathrm{M}$ & $\begin{array}{l}0.86 \\
1.26 \mathrm{M}\end{array}$ \\
\hline \multicolumn{7}{|l|}{ For Individuals in Medicaid } \\
\hline Family Income, $\%$ of FPL & $149 \%$ & $142 \%$ & $-7 \% * * *$ & $\begin{array}{l}-6.8 \\
-6.2 \%\end{array}$ & N/A & \\
\hline $\begin{array}{l}\text { Per capita medical out-of- } \\
\text { pocket spending }\end{array}$ & $\$ 376$ & $\$ 918$ & $\$ 542 * * *$ & $\begin{array}{l}\$ 516 \\
\$ 567\end{array}$ & N/A & \\
\hline
\end{tabular}

$* * * \mathrm{p}<0.001, * * \mathrm{p}<0.01, * \mathrm{p}<0.05$.

Numbers may not sum precisely due to rounding. $N=204,983$. From authors' analysis of the 2011 Current Population Survey. 


\section{Table VI:}

Poverty Reduction Attributable To Medicaid, by Gender, Race/Ethnicity, and Census Region

\begin{tabular}{|c|c|c|c|c|c|c|}
\hline \multirow[t]{2}{*}{ Subgroup } & \multicolumn{2}{|c|}{ Poverty Rate } & \multicolumn{2}{|c|}{ Extreme Poverty } & \multicolumn{2}{|c|}{$\frac{\text { Medical Out-of-Pocket }}{\text { Spending }}$} \\
\hline & $\begin{array}{l}\text { Reduction } \\
\text { due to } \\
\text { Medicaid in } \\
\text { percentage } \\
\text { points (SE) }\end{array}$ & $\begin{array}{l}\text { P-value for } \\
\text { between- } \\
\text { group } \\
\text { difference }\end{array}$ & $\begin{array}{l}\text { Reduction } \\
\text { due to } \\
\text { Medicaid in } \\
\text { percentage } \\
\text { points (SE) }\end{array}$ & $\begin{array}{l}\text { P-value } \\
\text { for } \\
\text { between- } \\
\text { group } \\
\text { difference }\end{array}$ & $\begin{array}{l}\text { Reduction } \\
\text { due to } \\
\text { Medicaid in } \\
\text { dollars (SE) }\end{array}$ & $\begin{array}{c}\text { P-value } \\
\text { for } \\
\text { between- } \\
\text { group } \\
\text { difference }\end{array}$ \\
\hline Race/Ethnicity & & & & & & \\
\hline White non-Hispanic & $0.4 \%(0.04)$ & reference & $0.3 \%(0.03)$ & reference & $\$ 501(\$ 46)$ & reference \\
\hline Black non-Hispanic & $1.5 \%(0.16)$ & $<0.001$ & $1.0 \%(0.13)$ & $<0.001$ & $\$ 524(\$ 63)$ & 0.77 \\
\hline Hispanic & $1.2 \%(0.12)$ & $<0.001$ & $0.8 \%(0.10)$ & $<0.001$ & $\$ 467(\$ 35)$ & 0.56 \\
\hline Other & $0.8 \%(0.22)$ & 0.057 & $0.4 \%(0.17)$ & 0.28 & $\$ 369(\$ 105)$ & 0.25 \\
\hline Gender & & & & & & \\
\hline Male & $0.6 \%(0.04)$ & reference & $0.4 \%(0.03)$ & reference & $\$ 465(\$ 39)$ & reference \\
\hline Female & $0.8 \%(0.04)$ & 0.026 & $0.5 \%(0.04)$ & 0.13 & $\$ 522(\$ 36)$ & 0.29 \\
\hline Region & & & & & & \\
\hline Northeast & $0.8 \%(0.09)$ & reference & $0.6 \%(0.07)$ & reference & $\$ 603(\$ 80)$ & reference \\
\hline Midwest & $0.6 \%(0.07)$ & 0.060 & $0.3 \%(0.07)$ & 0.035 & $\$ 466(\$ 65)$ & 0.18 \\
\hline South & $0.7 \%(0.06)$ & 0.42 & $0.5 \%(0.06)$ & 0.48 & $\$ 490(\$ 48)$ & 0.23 \\
\hline West & $0.7 \%(0.07)$ & 0.27 & $0.4 \%(0.07)$ & 0.12 & $\$ 445(\$ 53)$ & 0.10 \\
\hline
\end{tabular}

Note:

All estimates are from the stochastic model outlined in Section III.B, analogous to the full-sample results in Table III. Analyses use bootstrapped standard errors (SE) and t-tests to compare estimates across subgroups. N=204,983. From authors' analysis of the 2011 Current Population Survey. 


\section{Table VII: Poverty Reduction Attributable To Medicaid Among Institutionalized Populations}

\begin{tabular}{|c|c|c|c|c|c|c|}
\hline \multirow[t]{2}{*}{ Outcome } & \multicolumn{2}{|c|}{$\begin{array}{c}\text { Poverty Rate for all } \\
\text { Institutionalized Individuals }\end{array}$} & \multirow[b]{2}{*}{$\begin{array}{c}\text { Difference } \\
(\%)\end{array}$} & \multirow[b]{2}{*}{$95 \%$ CI } & \multirow[b]{2}{*}{$\begin{array}{l}\text { Difference } \\
\text { (Persons) }\end{array}$} & \multirow[b]{2}{*}{$95 \%$ CI } \\
\hline & $\begin{array}{l}\text { Status Quo } \\
\text { (with } \\
\text { Medicaid) }\end{array}$ & $\begin{array}{c}\text { Counterfactual } \\
\text { without } \\
\text { Medicaid }\end{array}$ & & & & \\
\hline $\begin{array}{l}\text { Poverty Rate } \\
(<100 \% \text { FPL })\end{array}$ & & & & & & \\
\hline - Children 0-18 & $96.5 \%$ & $98.2 \%$ & $1.7 \%$ & $\begin{array}{l}0.8 \% \\
2.6 \%\end{array}$ & $<0.01 \mathrm{M}$ & $\begin{array}{c}0 \\
0.01 \mathrm{M}\end{array}$ \\
\hline $\begin{array}{l}\text { - Nondisabled } \\
\text { Adults 19-64 }\end{array}$ & $85.6 \%$ & $88.4 \%$ & $2.8 \%$ & $\begin{array}{l}2.5 \\
3.0 \%\end{array}$ & $0.05 \mathrm{M}$ & $\begin{array}{l}0.04 \mathrm{M} \\
0.05 \mathrm{M}\end{array}$ \\
\hline $\begin{array}{l}\text { - Disabled Adults } \\
\text { 19-64 }\end{array}$ & $82.5 \%$ & $91.4 \%$ & $9.0 \%$ & $\begin{array}{l}8.2 \\
9.7 \%\end{array}$ & $0.07 \mathrm{M}$ & $\begin{array}{l}0.06 \mathrm{M} \\
0.08 \mathrm{M}\end{array}$ \\
\hline - Elderly & $46.6 \%$ & $74.8 \%$ & $28.2 \%$ & $\begin{array}{l}27.4 \\
29.0 \%\end{array}$ & $0.37 \mathrm{M}$ & $\begin{array}{l}0.36 \mathrm{M} \\
0.38 \mathrm{M}\end{array}$ \\
\hline Total & $72.8 \%$ & $85.0 \%$ & $12.2 \%$ & $\begin{array}{l}11.9 \\
12.6 \%\end{array}$ & $0.49 \mathrm{M}$ & $\begin{array}{l}0.48 \mathrm{M}, \\
0.50 \mathrm{M}\end{array}$ \\
\hline $\begin{array}{l}\text { Extreme Poverty } \\
\text { Rate }(<50 \% \text { FPL })\end{array}$ & & & & & & \\
\hline - Children 0-18 & $92.5 \%$ & $97.0 \%$ & $4.5 \%$ & $\begin{array}{l}3.3 \\
5.7 \%\end{array}$ & $0.01 \mathrm{M}$ & $\begin{array}{c}0, \\
0.01 \mathrm{M}\end{array}$ \\
\hline $\begin{array}{l}\text { - Nondisabled } \\
\text { Adults 19-64 }\end{array}$ & $77.9 \%$ & $82.8 \%$ & $4.9 \%$ & $\begin{array}{l}4.5 \\
5.2 \%\end{array}$ & $0.08 \mathrm{M}$ & $\begin{array}{l}0.08 \mathrm{M} \\
0.09 \mathrm{M}\end{array}$ \\
\hline $\begin{array}{l}\text { - Disabled Adults } \\
19-64\end{array}$ & $66.5 \%$ & $87.1 \%$ & $20.6 \%$ & $\begin{array}{l}19.6 \\
21.5 \%\end{array}$ & $0.16 \mathrm{M}$ & $\begin{array}{l}0.15 \mathrm{M} \\
0.17 \mathrm{M}\end{array}$ \\
\hline - Elderly & $18.9 \%$ & $65.6 \%$ & $46.8 \%$ & $\begin{array}{l}45.9 \\
47.7 \%\end{array}$ & $0.61 \mathrm{M}$ & $\begin{array}{l}0.60 \mathrm{M} \\
0.62 \mathrm{M}\end{array}$ \\
\hline Total & $57.1 \%$ & $78.7 \%$ & $21.6 \%$ & $\begin{array}{l}21.2 \\
22.0 \%\end{array}$ & $0.86 \mathrm{M}$ & $\begin{array}{l}0.85 \mathrm{M}, \\
0.88 \mathrm{M}\end{array}$ \\
\hline
\end{tabular}

Notes: $N=20,087$. From authors' analysis of the 2010 American Communities Survey. 


\section{Table VIII:}

\section{Comparison of Poverty-Reducing Impact of Means-Tested Public Programs,}

Among the U.S. Non-Institutionalized Population

Panel A: Poverty Rate (Less than $100 \%$ Federal Poverty Level)

\begin{tabular}{|l|ccc|c|}
\hline & \multicolumn{3}{|c|}{ Age Group } & Total Population \\
Poverty Rate & $\mathbf{0 - 1 8}$ & $\mathbf{1 9 - 6 4}$ & $\mathbf{6 5}+$ & \\
\hline Official Poverty Measure & $22.5 \%$ & $13.6 \%$ & $9.0 \%$ & $15.4 \%$ \\
Supplemental Poverty Measure (SPM) & $19.8 \%$ & $15.1 \%$ & $15.9 \%$ & $16.1 \%$ \\
Net Reduction in Poverty Rate (SPM) by Program & & & & \\
\hline Earned Income Tax Credit (EITC) & $3.9 \%$ & $1.4 \%$ & $0.2 \%$ & $1.9 \%$ \\
Supplemental Nutrition Assistance Program (SNAP) & $2.9 \%$ & $1.2 \%$ & $0.8 \%$ & $1.6 \%$ \\
Medicaid & $\mathbf{1 . 0 \%}$ & $\mathbf{0 . 6 \%}$ & $\mathbf{0 . 7 \%}$ & $\mathbf{0 . 7 \%}$ \\
Housing Assistance & $0.6 \%$ & $0.5 \%$ & $0.9 \%$ & $0.6 \%$ \\
Temporary Assistance to Needy Families (TANF) & $0.7 \%$ & $0.2 \%$ & $0.1 \%$ & $0.3 \%$ \\
School Lunch Program & $0.8 \%$ & $0.2 \%$ & $0.0 \%$ & $0.3 \%$ \\
Energy Assistance & $0.1 \%$ & $0.1 \%$ & $0.1 \%$ & $0.1 \%$ \\
Women, Infants, and Children (WIC) & $0.1 \%$ & $0.0 \%$ & $0.0 \%$ & $0.0 \%$ \\
\hline
\end{tabular}

Panel B: Extreme Poverty Rate (Less than 50\% Federal Poverty Level)

\begin{tabular}{|l|ccc|c|}
\hline & \multicolumn{3}{|c|}{ Age Group } & Total Population \\
Extreme Poverty Rate & $\mathbf{0 - 1 8}$ & $\mathbf{1 9 - 6 4}$ & $\mathbf{6 5}+$ & \\
\hline Official Poverty Measure & $10.6 \%$ & $6.4 \%$ & $2.5 \%$ & $7.0 \%$ \\
Supplemental Poverty Measure (SPM) & $5.5 \%$ & $5.5 \%$ & $4.7 \%$ & $5.4 \%$ \\
& & & & \\
Net Reduction in Extreme Poverty (SPM) by Program & & & & \\
\hline Supplemental Nutrition Assistance Program (SNAP) & $1.7 \%$ & $0.7 \%$ & $0.2 \%$ & $0.9 \%$ \\
Earned Income Tax Credit (EITC) & $1.2 \%$ & $0.5 \%$ & $0.1 \%$ & $0.6 \%$ \\
Medicaid & $\mathbf{0 . 6 \%}$ & $\mathbf{0 . 4 \%}$ & $\mathbf{0 . 4 \%}$ & $\mathbf{0 . 4 \%}$ \\
Housing Assistance & $0.4 \%$ & $0.3 \%$ & $0.2 \%$ & $0.3 \%$ \\
Temporary Assistance to Needy Families (TANF) & $0.4 \%$ & $0.1 \%$ & $0.0 \%$ & $0.2 \%$ \\
School Lunch Program & $0.3 \%$ & $0.1 \%$ & $0.0 \%$ & $0.1 \%$ \\
Energy Assistance & $0.0 \%$ & $0.0 \%$ & $0.0 \%$ & $0.0 \%$ \\
Women, Infants, and Children (WIC) & $0.0 \%$ & $0.0 \%$ & $0.0 \%$ & $0.0 \%$ \\
\hline
\end{tabular}


Appendix Table A.1:

Summary Statistics for Selected Propensity Score Deciles of Medicaid Coverage, Among Elderly Adults (65 and Over)

\begin{tabular}{|c|c|c|c|c|c|c|}
\hline \multirow[t]{2}{*}{ Variable } & \multicolumn{2}{|c|}{$\begin{array}{l}\text { Propensity Score Decile=1 } \\
\text { (Low likelihood Medicaid) }\end{array}$} & \multicolumn{2}{|c|}{$\begin{array}{c}\text { Propensity Score Decile=5 } \\
\text { (Medium likelihood Medicaid) }\end{array}$} & \multicolumn{2}{|c|}{$\begin{array}{l}\text { Propensity Score Decile }=10 \\
\text { (High likelihood Medicaid) }\end{array}$} \\
\hline & Not in Medicaid & Medicaid & Not in Medicaid & Medicaid & Not in Medicaid & Medicaid \\
\hline Age & 73.6 & 73.4 & 74.7 & 74.2 & 72.9 & 74.4 \\
\hline Male & $49.5 \%$ & $51.6 \%$ & $37.4 \%$ & $34.7 \%$ & $32.7 \%$ & $26.5 \%$ \\
\hline Married & $72.7 \%$ & $64.8 \%$ & $38.5 \%$ & $37.4 \%$ & $21.3 \%$ & $20.1 \%$ \\
\hline White & $96.9 \%$ & $95.9 \%$ & $63.5 \%$ & $61.6 \%$ & $66.0 \%$ & $53.9 \%$ \\
\hline Black & $1.5 \%$ & $3.2 \%$ & $23.3 \%$ & $25.1 \%$ & $22.0 \%$ & $28.3 \%$ \\
\hline Latino & $0.0 \%$ & $0.0 \%$ & $21.6 \%$ & $17.4 \%$ & $56.0 \%$ & $40.2 \%$ \\
\hline Education & & & & & & \\
\hline$-<12^{\text {th }}$ Grade & $2.1 \%$ & $1.4 \%$ & $46.4 \%$ & $43.4 \%$ & $84.0 \%$ & $81.7 \%$ \\
\hline -High School & $65.5 \%$ & $66.7 \%$ & $42.6 \%$ & $49.3 \%$ & $14.7 \%$ & $14.6 \%$ \\
\hline -College Graduate & $32.4 \%$ & $32.0 \%$ & $11.0 \%$ & $7.3 \%$ & $1.3 \%$ & $3.7 \%$ \\
\hline Working Full-time & $13.6 \%$ & $16.0 \%$ & $2.6 \%$ & $0.9 \%$ & $2.0 \%$ & $0.0 \%$ \\
\hline $\begin{array}{l}\text { Family Income } \\
(\% \text { FPL })\end{array}$ & $502 \%$ & $459 \%$ & $221 \%$ & $199 \%$ & $82 \%$ & $103 \%$ \\
\hline Non-Citizen & $0.5 \%$ & $0.9 \%$ & $8.5 \%$ & $9.1 \%$ & $34.7 \%$ & $21.0 \%$ \\
\hline Health & & & & & & \\
\hline -Excellent & $15.9 \%$ & $13.2 \%$ & $3.3 \%$ & $2.7 \%$ & $3.3 \%$ & $1.4 \%$ \\
\hline -Very Good & $34.4 \%$ & $34.2 \%$ & $8.0 \%$ & $5.9 \%$ & $9.3 \%$ & $5.0 \%$ \\
\hline -Good & $39.5 \%$ & $42.5 \%$ & $27.3 \%$ & $25.1 \%$ & $26.0 \%$ & $13.2 \%$ \\
\hline -Fair/Poor & $10.2 \%$ & $10.0 \%$ & $61.4 \%$ & $66.2 \%$ & $61.3 \%$ & $80.4 \%$ \\
\hline Imputed Eligible§ & $1.0 \%$ & $3.2 \%$ & $21.1 \%$ & $21.0 \%$ & $98.7 \%$ & $98.6 \%$ \\
\hline Actual Insurance* & & & & & & \\
\hline -Medicaid & $0.0 \%$ & $100.0 \%$ & $0.0 \%$ & $100.0 \%$ & $0.0 \%$ & $100.0 \%$ \\
\hline -Private Insurance & $72.1 \%$ & $58.0 \%$ & $41.1 \%$ & $19.6 \%$ & $15.3 \%$ & $8.7 \%$ \\
\hline -Medicare & $92.6 \%$ & $95.9 \%$ & $92.5 \%$ & $98.6 \%$ & $72.0 \%$ & $98.6 \%$ \\
\hline -Uninsured & $0.8 \%$ & $0.0 \%$ & $4.0 \%$ & $0.0 \%$ & $22.7 \%$ & $0.0 \%$ \\
\hline $\begin{array}{l}\text { Out-of-pocket } \\
\text { medical spending }\end{array}$ & $\$ 2,544$ & $\$ 1,721$ & $\$ 1,806$ & $\$ 693$ & $\$ 822$ & $\$ 549$ \\
\hline Cell Size & $N=8054$ & $N=219$ & $N=875$ & $N=219$ & $N=150$ & $N=219$ \\
\hline
\end{tabular}

Note:

§ Eligibility information used for this imputation does not include medical need or "spend-down" provisions, which is why some individuals reporting Medicaid do not appear eligible by income standards alone. Reporting error in income or coverage type may similarly produce apparently ineligible Medicaid beneficiaries.

* Individuals may report multiple forms of insurance in the Current Population Survey, so numbers sum to more than $100 \%$. 
Appendix Table A.2:

Summary Statistics for Selected Propensity Score Deciles of Medicaid Coverage, Among Disabled Adults (19-64)

\begin{tabular}{|c|c|c|c|c|c|c|}
\hline \multirow[t]{2}{*}{ Variable } & \multicolumn{2}{|c|}{$\begin{array}{l}\text { Propensity Score Decile=1 } \\
\text { (Low likelihood Medicaid) }\end{array}$} & \multicolumn{2}{|c|}{$\begin{array}{c}\text { Propensity Score Decile=5 } \\
\text { (Medium likelihood Medicaid) }\end{array}$} & \multicolumn{2}{|c|}{$\begin{array}{l}\text { Propensity Score Decile=10 } \\
\text { (High likelihood Medicaid) }\end{array}$} \\
\hline & Not in Medicaid & Medicaid & Not in Medicaid & Medicaid & Not in Medicaid & Medicaid \\
\hline Age & 53.6 & 53.6 & 45.6 & 47.7 & 36.1 & 38.0 \\
\hline Male & $52.6 \%$ & $57.6 \%$ & $49.3 \%$ & $42.6 \%$ & $40.9 \%$ & $32.8 \%$ \\
\hline Married & $73.8 \%$ & $70.5 \%$ & $27.4 \%$ & $22.0 \%$ & $4.5 \%$ & $6.1 \%$ \\
\hline White & $82.8 \%$ & $80.4 \%$ & $69.6 \%$ & $62.9 \%$ & $72.7 \%$ & $61.7 \%$ \\
\hline Black & $11.0 \%$ & $11.3 \%$ & $22.2 \%$ & $25.5 \%$ & $25.8 \%$ & $27.3 \%$ \\
\hline Latino & $7.7 \%$ & $11.6 \%$ & $17.6 \%$ & $13.5 \%$ & $12.1 \%$ & $24.0 \%$ \\
\hline $\begin{array}{l}\text { Education } \\
-<12^{\text {th }} \text { Grade }\end{array}$ & $5.6 \%$ & $6.1 \%$ & $30.6 \%$ & $27.7 \%$ & $53.0 \%$ & $59.2 \%$ \\
\hline -High School & $69.9 \%$ & $71.3 \%$ & $64.2 \%$ & $66.8 \%$ & $47.0 \%$ & $38.6 \%$ \\
\hline -College Graduate & $24.5 \%$ & $22.6 \%$ & $5.1 \%$ & $5.5 \%$ & $0.0 \%$ & $2.2 \%$ \\
\hline Working Full-time & $15.5 \%$ & $8.8 \%$ & $1.9 \%$ & $1.9 \%$ & $0.0 \%$ & $0.0 \%$ \\
\hline $\begin{array}{l}\text { Family Income } \\
(\% \text { FPL })\end{array}$ & $436 \%$ & $349 \%$ & $137 \%$ & $125 \%$ & $55 \%$ & $70 \%$ \\
\hline Non-Citizen & $3.5 \%$ & $4.7 \%$ & $5.7 \%$ & $4.7 \%$ & $0.0 \%$ & $3.3 \%$ \\
\hline Health & & & & & & \\
\hline -Excellent & $6.4 \%$ & $5.0 \%$ & $2.7 \%$ & $3.6 \%$ & $3.0 \%$ & $1.7 \%$ \\
\hline -Very Good & $13.7 \%$ & $9.6 \%$ & $7.3 \%$ & $4.7 \%$ & $1.5 \%$ & $2.2 \%$ \\
\hline -Good & $26.1 \%$ & $23.7 \%$ & $20.3 \%$ & $22.3 \%$ & $22.7 \%$ & $24.5 \%$ \\
\hline -Fair/Poor & $53.7 \%$ & $61.7 \%$ & $69.6 \%$ & $69.5 \%$ & $72.7 \%$ & $71.6 \%$ \\
\hline Imputed Eligible§ & $4.0 \%$ & $7.7 \%$ & $60.7 \%$ & $58.0 \%$ & $97.0 \%$ & $95.6 \%$ \\
\hline Actual Insurance* & & & & & & \\
\hline -Medicaid & $0.0 \%$ & $100.0 \%$ & $0.0 \%$ & $100.0 \%$ & $0.0 \%$ & $100.0 \%$ \\
\hline -Private Insurance & $65.8 \%$ & $35.5 \%$ & $30.4 \%$ & $12.4 \%$ & $18.2 \%$ & $4.4 \%$ \\
\hline -Medicare & $29.9 \%$ & $46.3 \%$ & $30.9 \%$ & $36.5 \%$ & $27.3 \%$ & $24.5 \%$ \\
\hline -Uninsured & $13.0 \%$ & $0.0 \%$ & $38.8 \%$ & $0.0 \%$ & $54.5 \%$ & $0.0 \%$ \\
\hline $\begin{array}{l}\text { Out-of-pocket } \\
\text { medical spending }\end{array}$ & $\$ 3,143$ & $\$ 2,118$ & $\$ 1,976$ & $\$ 841$ & $\$ 1,103$ & $\$ 480$ \\
\hline Cell Size & $N=2524$ & $N=363$ & $N=369$ & $N=364$ & $N=66$ & $N=363$ \\
\hline
\end{tabular}

Note:

$\S$ Eligibility information used for this imputation does not include medical need or "spend-down" provisions, which is why some individuals reporting Medicaid do not appear eligible by income standards alone. Reporting error in income or coverage type may similarly produce apparently ineligible Medicaid beneficiaries.

* Individuals may report multiple forms of insurance in the Current Population Survey, so numbers sum to more than $100 \%$. 
Appendix Table A.3:

Summary Statistics for Selected Propensity Score Deciles of Medicaid Coverage, Among Non-Disabled Parents (19-64)†

\begin{tabular}{|c|c|c|c|c|c|c|}
\hline \multirow[t]{2}{*}{ Variable } & \multicolumn{2}{|c|}{$\begin{array}{l}\text { Propensity Score Decile=1 } \\
\text { (Low likelihood Medicaid) }\end{array}$} & \multicolumn{2}{|c|}{$\begin{array}{c}\text { Propensity Score Decile=5 } \\
\text { (Medium likelihood Medicaid) }\end{array}$} & \multicolumn{2}{|c|}{$\begin{array}{l}\text { Propensity Score Decile }=10 \\
\text { (High likelihood Medicaid) }\end{array}$} \\
\hline & Not in Medicaid & Medicaid & Not in Medicaid & Medicaid & Not in Medicaid & Medicaid \\
\hline Age & 42.6 & 41.4 & 35.0 & 34.5 & 31.3 & 30.0 \\
\hline Male & $52.7 \%$ & $57.3 \%$ & $35.2 \%$ & $30.1 \%$ & $26.2 \%$ & $19.8 \%$ \\
\hline Married & $92.2 \%$ & $91.0 \%$ & $58.3 \%$ & $51.5 \%$ & $22.9 \%$ & $26.2 \%$ \\
\hline White & $87.0 \%$ & $86.3 \%$ & $73.9 \%$ & $75.1 \%$ & $54.8 \%$ & $56.9 \%$ \\
\hline Black & $4.1 \%$ & $5.7 \%$ & $15.6 \%$ & $18.0 \%$ & $36.2 \%$ & $38.4 \%$ \\
\hline Latino & $14.9 \%$ & $27.2 \%$ & $35.9 \%$ & $28.8 \%$ & $11.4 \%$ & $17.4 \%$ \\
\hline \multicolumn{7}{|l|}{ Education } \\
\hline$-<12^{\text {th }}$ Grade & $4.6 \%$ & $13.1 \%$ & $28.7 \%$ & $26.0 \%$ & $27.1 \%$ & $29.7 \%$ \\
\hline -High School & $46.3 \%$ & $53.0 \%$ & $63.1 \%$ & $66.5 \%$ & $67.1 \%$ & $66.7 \%$ \\
\hline -College Graduate & $49.1 \%$ & $33.9 \%$ & $8.2 \%$ & $7.6 \%$ & $5.7 \%$ & $3.7 \%$ \\
\hline Working Full-time & $75.1 \%$ & $73.8 \%$ & $30.6 \%$ & $27.0 \%$ & $19.5 \%$ & $13.7 \%$ \\
\hline $\begin{array}{l}\text { Family Income } \\
\text { (\%FPL) }\end{array}$ & $542 \%$ & $406 \%$ & $134 \%$ & $131 \%$ & $63 \%$ & $66 \%$ \\
\hline Non-Citizen & $9.5 \%$ & $22.9 \%$ & $23.5 \%$ & $17.8 \%$ & $8.6 \%$ & $7.8 \%$ \\
\hline \multicolumn{7}{|l|}{ Health } \\
\hline -Excellent & $39.8 \%$ & $36.4 \%$ & $19.2 \%$ & $19.6 \%$ & $22.4 \%$ & $23.7 \%$ \\
\hline -Very Good & $40.9 \%$ & $36.0 \%$ & $32.7 \%$ & $29.2 \%$ & $36.2 \%$ & $27.4 \%$ \\
\hline -Good & $18.0 \%$ & $24.3 \%$ & $35.0 \%$ & $40.3 \%$ & $26.2 \%$ & $31.7 \%$ \\
\hline -Fair/Poor & $1.4 \%$ & $3.3 \%$ & $13.0 \%$ & $10.8 \%$ & $15.2 \%$ & $17.2 \%$ \\
\hline Imputed Eligible $\S$ & $0.5 \%$ & $2.5 \%$ & $53.8 \%$ & $49.5 \%$ & $100.0 \%$ & $100.0 \%$ \\
\hline \multicolumn{7}{|l|}{ Actual Insurance* } \\
\hline -Medicaid & $0.0 \%$ & $100.0 \%$ & $0.0 \%$ & $100.0 \%$ & $0.0 \%$ & $100.0 \%$ \\
\hline -Private Insurance & $89.2 \%$ & $52.1 \%$ & $39.6 \%$ & $15.1 \%$ & $39.0 \%$ & $7.0 \%$ \\
\hline -Medicare & $0.1 \%$ & $2.9 \%$ & $1.0 \%$ & $1.2 \%$ & $2.9 \%$ & $2.0 \%$ \\
\hline -Uninsured & $9.6 \%$ & $0.0 \%$ & $57.7 \%$ & $0.0 \%$ & $57.1 \%$ & $0.0 \%$ \\
\hline $\begin{array}{l}\text { Out-of-pocket } \\
\text { medical spending }\end{array}$ & $\$ 2,349$ & $\$ 1,246$ & $\$ 1,129$ & $\$ 431$ & $\$ 989$ & $\$ 267$ \\
\hline Cell Size & $N=28,159$ & $N=489$ & $N=1466$ & $N=490$ & $N=210$ & $N=489$ \\
\hline
\end{tabular}

Note:

$\dagger$ 'Parent' means parent of a dependent child in the home, which is the relevant criterion for Medicaid eligibility.

$\S$ Eligibility information used for this imputation does not include medical need or "spend-down" provisions, which is why some individuals reporting Medicaid do not appear eligible by income standards alone. Reporting error in income or coverage type may similarly produce apparently ineligible Medicaid beneficiaries.

* Individuals may report multiple forms of insurance in the Current Population Survey, so numbers sum to more than $100 \%$. 
Appendix Table A.4:

Summary Statistics for Selected Propensity Score Deciles of Medicaid Coverage, Among

Childless Adults (19-64) $\dagger$

\begin{tabular}{|c|c|c|c|c|c|c|}
\hline \multirow[t]{2}{*}{ Variable } & \multicolumn{2}{|c|}{$\begin{array}{l}\text { Propensity Score Decile=1 } \\
\text { (Low likelihood Medicaid) }\end{array}$} & \multicolumn{2}{|c|}{$\begin{array}{c}\text { Propensity Score Decile }=5 \\
\text { (Medium likelihood Medicaid) }\end{array}$} & \multicolumn{2}{|c|}{$\begin{array}{l}\text { Propensity Score Decile }=10 \\
\text { (High likelihood Medicaid) }\end{array}$} \\
\hline & Not in Medicaid & Medicaid & Not in Medicaid & Medicaid & Not in Medicaid & Medicaid \\
\hline Age & 44.7 & 43.6 & 36.2 & 34.8 & 37.1 & 39.1 \\
\hline Male & $56.8 \%$ & $56.3 \%$ & $47.9 \%$ & $44.0 \%$ & $43.5 \%$ & $42.8 \%$ \\
\hline Married & $51.0 \%$ & $48.8 \%$ & $26.8 \%$ & $22.9 \%$ & $13.9 \%$ & $17.2 \%$ \\
\hline White & $84.3 \%$ & $88.3 \%$ & $68.6 \%$ & $68.1 \%$ & $60.8 \%$ & $52.1 \%$ \\
\hline Black & $5.7 \%$ & $5.4 \%$ & $19.7 \%$ & $19.6 \%$ & $32.1 \%$ & $40.4 \%$ \\
\hline Latino & $10.6 \%$ & $11.7 \%$ & $26.1 \%$ & $23.2 \%$ & $18.9 \%$ & $22.3 \%$ \\
\hline Education & & & & & & \\
\hline$-<12^{\text {th }}$ Grade & $0.6 \%$ & $1.2 \%$ & $24.3 \%$ & $18.4 \%$ & $35.4 \%$ & $48.5 \%$ \\
\hline -High School & $55.0 \%$ & $66.0 \%$ & $65.0 \%$ & $74.1 \%$ & $52.2 \%$ & $47.6 \%$ \\
\hline -College Graduate & $44.4 \%$ & $32.8 \%$ & $10.7 \%$ & $7.5 \%$ & $12.4 \%$ & $3.9 \%$ \\
\hline Working Full-time & $78.1 \%$ & $70.2 \%$ & $21.7 \%$ & $18.1 \%$ & $7.7 \%$ & $5.1 \%$ \\
\hline $\begin{array}{l}\text { Family Income } \\
(\% \text { FPL })\end{array}$ & $622 \%$ & $534 \%$ & $224 \%$ & $203 \%$ & $83 \%$ & $75 \%$ \\
\hline Non-Citizen & $8.1 \%$ & $9.6 \%$ & $14.4 \%$ & $9.6 \%$ & $7.4 \%$ & $8.7 \%$ \\
\hline Health & & & & & & \\
\hline -Excellent & $35.8 \%$ & $32.5 \%$ & $25.6 \%$ & $25.6 \%$ & $19.4 \%$ & $13.3 \%$ \\
\hline -Very Good & $41.6 \%$ & $40.4 \%$ & $28.4 \%$ & $27.4 \%$ & $23.2 \%$ & $19.6 \%$ \\
\hline -Good & $22.4 \%$ & $26.8 \%$ & $30.3 \%$ & $35.8 \%$ & $23.2 \%$ & $26.2 \%$ \\
\hline -Fair/Poor & $0.3 \%$ & $0.3 \%$ & $15.7 \%$ & $11.1 \%$ & $34.2 \%$ & $41.0 \%$ \\
\hline Imputed Eligible§ & $0.2 \%$ & $0.0 \%$ & $19.7 \%$ & $22.9 \%$ & $86.4 \%$ & $92.5 \%$ \\
\hline $\begin{array}{l}\text { Actual Insurance* } \\
\text {-Medicaid }\end{array}$ & & & $00 \%$ & & $0 \Omega \%$ & \\
\hline -Private Insurance & $\begin{array}{c}0.0 \% \\
83.8 \%\end{array}$ & $\begin{array}{l}100.0 \% \\
58.4 \%\end{array}$ & $\begin{array}{c}0.0 \% \\
48.5 \%\end{array}$ & $\begin{array}{c}100.0 \% \\
19.9 \%\end{array}$ & $\begin{array}{c}0.0 \% \\
29.7 \%\end{array}$ & $\begin{array}{l}100.0 \% \\
8.1 \%\end{array}$ \\
\hline -Medicare & $0.5 \%$ & $5.7 \%$ & $2.6 \%$ & $4.5 \%$ & $6.9 \%$ & $11.4 \%$ \\
\hline -Uninsured & $14.7 \%$ & $0.0 \%$ & $47.9 \%$ & $0.0 \%$ & $62.2 \%$ & $0.0 \%$ \\
\hline $\begin{array}{l}\text { Out-of-pocket } \\
\text { medical spending }\end{array}$ & $\$ 1,959$ & $\$ 1,696$ & $\$ 937$ & $\$ 736$ & $\$ 828$ & $\$ 246$ \\
\hline Cell Size & $N=24,929$ & $N=332$ & $N=3394$ & $N=332$ & $N=418$ & $N=332$ \\
\hline
\end{tabular}

Note:

$\dagger$ 'Childless Adults' means non-disabled adults, without any dependent children living in the home.

$\S$ Eligibility information used for this imputation does not include medical need or "spend-down" provisions, which is why some individuals reporting Medicaid do not appear eligible by income standards alone. Reporting error in income or coverage type may similarly produce apparently ineligible Medicaid beneficiaries.

* Individuals may report multiple forms of insurance in the Current Population Survey, so numbers sum to more than $100 \%$. 